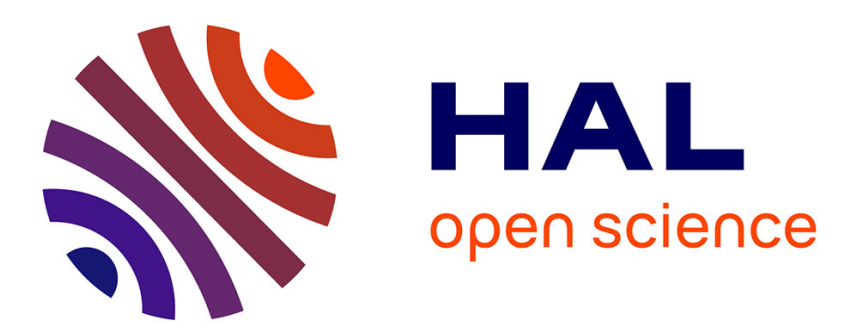

\title{
Experimental constraints on metasomatism of mantle wedge peridotites by hybridized adakitic melts
}

\author{
Alexandre Corgne, Manuel Schilling, Michel Grégoire, Jessica Langlade
}

\section{To cite this version:}

Alexandre Corgne, Manuel Schilling, Michel Grégoire, Jessica Langlade. Experimental constraints on metasomatism of mantle wedge peridotites by hybridized adakitic melts. Lithos, 2018, 308-309, pp.213-226. 10.1016/j.lithos.2018.03.006 . hal-02332117

\section{HAL Id: hal-02332117 \\ https://hal.science/hal-02332117}

Submitted on 13 Nov 2020

HAL is a multi-disciplinary open access archive for the deposit and dissemination of scientific research documents, whether they are published or not. The documents may come from teaching and research institutions in France or abroad, or from public or private research centers.
L'archive ouverte pluridisciplinaire HAL, est destinée au dépôt et à la diffusion de documents scientifiques de niveau recherche, publiés ou non, émanant des établissements d'enseignement et de recherche français ou étrangers, des laboratoires publics ou privés. 


\section{Accepted Manuscript}

Experimental constraints on metasomatism of mantle wedge peridotites by hybridized adakitic melts

Alexandre Corgne, Manuel E. Schilling, Michel Grégoire, Jessica Langlade

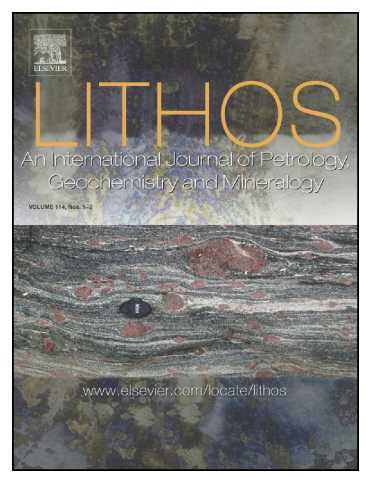

PII:

S0024-4937(18)30093-8

DOI: doi:10.1016/j.lithos.2018.03.006

Reference: LITHOS 4596

To appear in:

Received date: 20 December 2017

Accepted date: 6 March 2018

Please cite this article as: Alexandre Corgne, Manuel E. Schilling, Michel Grégoire, Jessica Langlade, Experimental constraints on metasomatism of mantle wedge peridotites by hybridized adakitic melts. The address for the corresponding author was captured as affiliation for all authors. Please check if appropriate. Lithos(2018), doi:10.1016/ j.lithos.2018.03.006

This is a PDF file of an unedited manuscript that has been accepted for publication. As a service to our customers we are providing this early version of the manuscript. The manuscript will undergo copyediting, typesetting, and review of the resulting proof before it is published in its final form. Please note that during the production process errors may be discovered which could affect the content, and all legal disclaimers that apply to the journal pertain. 
Experimental constraints on metasomatism of mantle wedge peridotites by hybridized adakitic melts

Alexandre Corgne ${ }^{1,2, \star}$, Manuel E. Schilling ${ }^{1}$, Michel Grégoire ${ }^{3}$, Jessica Langlade ${ }^{4}$

${ }^{1}$ Instituto de Ciencias de la Tierra, Universidad Austral de Chile, Valdivia, Chile

${ }^{2}$ Centre National de la Recherche Scientifique, France

${ }^{3}$ Géosciences Environnement Toulouse, Observatoire Midi-Pyrénées, Toulouse, France

${ }^{4}$ Institut Universitaire Européen de la Mer, Plouzané, France

*corresponding author: alexandre.corgne@uach.cl

\section{Submitted to Lithos}




\section{Abstract}

In this study, a series of high-pressure $(1.5 \mathrm{GPa})$ and high-temperature $\left(1000-1300{ }^{\circ} \mathrm{C}\right)$ experiments were performed to investigate the petrological imprints of adakitic metasomatism on mantle wedge peridotites. Reaction couples were prepared using a powdered adakite from Cerro Pampa, Argentina (Mg\# 0.7) placed in contact with a cored sample of medium-grained protogranular depleted spinel Iherzolite from Pali Aike (Chile). Textural and chemical analyses of the run products allow us to identify key features of modal metasomatism by hybridized adakitic melts. The main changes in phase relations are associated with the following metasomatic reactions: incongruent dissolution of olivine and associated precipitation of secondary orthopyroxene, dissolution of primary spinel and subsequent replacement by secondary high-Cr spinel. In experiments with high water contents (9-12 wt\%), precipitation of pargasitic amphibole also occurred, possibly at the expense of primary clinopyroxene. Neither phlogopite nor Ti-oxides were precipitated in any of these experiments. As expected, primary pyroxenes do not show evidence of being significantly altered following the interaction with the produced siliceous melts. Within the adakitic portion of the experimental charge, it was also observed the crystallization of secondary Ti-rich, $\mathrm{Cr}$ - and Na-poor diopsidic clinopyroxene, andesine plagioclase and, at low temperature, Fe-enriched secondary orthopyroxene. Considering textural criteria, we interpreted the formation of these minerals as crystallization products of the adakite component and not as true products of metasomatic reactions. The experimental results are used to discuss some of the petrological evidences presented to support modal metasomatism by slab-derived melts of mantle xenoliths extracted from several suprasubduction settings located around the Pacific Ring of Fire. Keywords: Adakite; Mantle wedge; Metasomatism; Pargasite; Peridotite; Subduction 


\section{Introduction}

Reactive percolation of a wide variety of melts and fluids has been used to explain the mineralogy and composition of mantle samples brought to Earth's surface. In that regard, peridotite xenoliths carried to the surface by volcanic activity provide important constraints on the nature and evolution of the lithospheric mantle (e.g. Brandon et al., 1999; Pearson et al., 2003). The purpose and difficulty in studying mantle xenoliths, which include spinel/garnet harzburgites, spinel/garnet Iherzolites, spinel websterites, wehrlites, dunites and pyroxenites, lie in decrypting their complex history of depletion and/or enrichment following partial melting and metasomatism. Source heterogeneities accumulated over time during successive tectonic events also add to the xenolith complexity (e.g. Arai and Ishimaru, 2008). From the study of mantle xenoliths, it has been proposed that the subcontinental lithospheric mantle wedge has undergone variable degrees of melt extraction and distinct types of metasomatism. For example, in the sub-Patagonian mantle wedge, which has been linked to a long-lasting convergent margin, petrographic and geochemical observations have led some authors to call upon carbonatitic metasomatism ascribed either to the asthenosphere (Bjerg et al., 2009; Gorring and Kay, 2000) or to the subducted slab (Laurora et al., 2001), adakitic metasomatism (Faccini et al., 2013; Kilian and Stern, 2002; Wang et al., 2007), K-rich fluid metasomatism (Rivalenti et al., 2007) and alkali and tholeiitic basalt metasomatism (Dantas et al., 2009; Schilling et al., 2005; Wang et al., 2008a, 2008b). Other authors did not find any evidence for metasomatism in some mantle xenoliths (e.g. Ntaflos et al., 2007). The possible consequences of potential melt/fluid metasomatism on the geochemistry of the subcontinental mantle wedge have therefore been relatively well documented from the petrological study of mantle xenoliths. However, the exact nature of the metasomatic agents remains unclear in many cases. This unknown has direct implications for the origin and evolution of 
subcontinental mantle domains. At the sample scale, the origin of chemical patterns and textures in mantle xenoliths has remained controversial. Reaction textures of interest include partial mineral replacement, orthopyroxene and clinopyroxene rims, websterite veins, glassbearing sieve-textured clinopyroxene and spinel, glassy pockets around spinel and amphibole, phlogopite precipitation and carbonate inclusions.

One way to understand more precisely the relative contributions of proposed metasomatic agents in mantle heterogeneities is to simulate in a laboratory the exchange reactions that may take place in the subcontinental lithospheric mantle. Direct comparison between results from controlled experiments and observations from natural samples will help us improve our understanding of the evolution of the upper mantle located above the subducting slab. This is the approach followed in the present study, focusing on the chemical reactions and mineralogical transformations of spinel Therzolite associated with adakitic (sensu stricto) metasomatism. According to the initial definition of Defant and Drummond (1990), the origin of adakites is ascribed to slab melting. This geological context is particularly relevant for the mantle wedge, which may have witnessed the subduction of young tectonic plates sufficiently hot to partially melt. In Patagonia for example, this process would have produced the dacitic lavas of Cerro Pampa, Chaltén and Puesto Nuevo, on the western part of the back-arc domain (Kay et al., 1993; Ramos et al., 2004), as well as the currently erupting adakites along the Austral Volcanic Zone (Kilian and Stern, 2002; Stern and Kilian, 1996).

As detailed hereafter, we were able to use a novel experimental approach to study melt metasomatism of a depleted spinel Iherzolite with medium-grained protogranular texture, which is the type of texture expected for pristine depleted mantle (e.g. Arai and Kida, 2000; 
Mercier and Nicolas, 1975). Our experimental results allow us to constrain key features of modal metasomatism by adakitic (slab-derived) melts. These findings are then compared to those from previous experimental works to extend our understanding of this type of metasomatism, knowing that the composition of slab-derived melts is variable depending on degree of melting, source heterogeneities and subsequent hybridization with mantle materials. The combined experimental dataset allow us to shed light on the expected variations in phase relations and chemistry of the metasomatic products. Finally, we used these experimental constraints to discuss evidence of adakitic metasomatism interpreted from previous petrological studies of mantle xenoliths from several localities on the eastern, western and northern border of the Pacific Ocean (Argentina, Kamchatka, Japan, Papua New Guinea, Philippines and Alaska).

\section{Methods}

To simulate the exchange reactions that may take place in the subcontinental lithospheric mantle, we performed high-pressure and high-temperature laboratory experiments on cell assemblies containing reaction couples made of adakitic and peridotitic materials in contact with one another, thereby generating reactions between adakitic melt and minerals typically encountered in the mantle wedge. Details of the experimental procedure are presented below.

\subsection{Starting Materials}

Reaction couples were prepared using powdered natural adakite from Cerro Pampa (Argentina) in contact with a 4-mm-diameter cylindrical section of a natural spinel Iherzolite. The cylindrical sections were prepared using diamond core drill bits by drilling through a finely polished block of the spinel Iherzolite. The purpose of polishing the surface of the block was 
to generate a neat interface between the Iherzolite and the adakite powder. Initial adakite/lherzolite weight ratios range from 0.2 to 0.4 . The lherzolite sample is a fresh anhydrous xenolith from Laguna Timone, Pali Aike, Chile (sample PM18-2). It consists of a medium-grained (1-2 mm) protogranular assemblage of olivine (Ol), clinopyroxene (Cpx), orthopyroxene (Opx) and spinel (Sp), devoid of evident modal metasomatism. Gervasoni et al. (2012) previously reported whole-rock major and trace element compositions for this Iherzolite sample (see also Table 1). In this study, we further document the texture and geochemistry of the sample. The petrography and phase compositions are briefly presented in section 3 and further detailed in the electronic supplementary material. As for the Cerro Pampa adakite, major and trace element composition was determined using ALS Chemex laboratory in Sevilla, Spain, which combined certified ICP-MS and ICP-AES analyzes using standard procedures. A glass bead of the Cerro Pampa adakite was also synthesized experimentally from a melting experiment at $2 \mathrm{GPa}$ and $1400{ }^{\circ} \mathrm{C}$. Element contents of the glass bead measured by EPMA and LA-ICP-MS (see section 2.2 for details) are in agreement with the independent measurement made by ALS Chemex (Table 1). Given its relatively high Mg-number (Mg\#, molar $\left.\mathrm{Mg} /\left(\mathrm{Mg}+\mathrm{Fe}^{2+}\right)\right)$ and $\mathrm{Cr}$ and $\mathrm{Ni}$ contents, the adakite represents a hybrid slab melt that has suffered some degree of mantle assimilation, rather than a truly pristine slab melt (Kay et al., 1993; Rapp et al., 1999). Variable amounts of distilled and deionized water were added by micropipette to some of the reaction couples to study its contribution to adakitic metasomatism.

\subsection{Experimental method}

High-pressure and high-temperature experiments were performed in an end-loaded pistoncylinder apparatus at the Institut de Physique du Globe de Paris (France) using both 1/2" and 
3/4" talc-pyrex cell assemblies. Both assemblies consist of a straight walled graphite furnace, talc pressure medium and thermal insulator, a Pyrex-sleeve as a viscous barrier against talc infiltration, and magnesia and alumina inner spacers and tubing. The cylindrical platinum capsules containing the reaction couple were partially lined with graphite to minimize Fe-loss and maintain the oxygen fugacity of the experiments between the $\mathrm{CCO}$ and FMQ buffers, which corresponds to conditions generally encountered in the subcontinental mantle (e.g. Arai and Ishimaru, 2008). Experiments were carried out at $1.5 \mathrm{GPa}$ (equivalent to about $50 \mathrm{~km}$ depth) and $1000-1300{ }^{\circ} \mathrm{C}$ (Table 2). This temperature range lies on the upper end of those estimated at $50 \mathrm{~km}$ depth in the mantle wedge (e.g. Syracuse et al., 2010). In each experiment, the reaction couple was first pressurized to the target pressure (1.5 GPa). The temperature was then increased to the target value at a rate of $100^{\circ} \mathrm{C} / \mathrm{min}$ and held there for a duration varying between 48 and $120 \mathrm{~h}$. Temperature was monitored with W-Re thermocouples inserted axially near the platinum capsule. After run completion, samples were quenched rapidly by turning off the power to the graphite furnace and subsequently decompressed. Recovered capsules were mounted in acrylic resin, sectioned longitudinally to expose the reaction interface, and polished to a $1 \mu \mathrm{m}$ finish for SEM, EPMA and LA-ICP-MS analyses.

\subsection{Analytical methods}

Conventional SEM observations were made with a ZEISS electron microscope at the Institut de Physique du Globe de Paris (France) to characterize the original texture of the studied samples, as well as the reactions and textural evolution taking place in each sample. These observations and semi-quantitative EDS analyses were used to detect points of interest for subsequent fully quantitative analyses. Major and minor element compositions of the run 
products and the original phases were determined with a CAMECA SX100 microprobe at the Institut Universitaire Européen de la Mer (Plouzané, France), using wavelength-dispersive spectrometry. The electron microprobe used a standard setup: beam current of $20 \mathrm{nA}$ and an acceleration voltage of $15 \mathrm{kV}, 10-30 \mathrm{~s}$ of peak counting, $10 \mathrm{~s}$ of background counting, utilizing natural and synthetic minerals as calibration standards. Trace element concentrations of some of the run products were determined in-situ by LA-ICP-MS at the Institut Universitaire Européen de la Mer, with a Thermo Element 2 ICP-MS coupled to a CompexPro 102 laser ablation module that uses a $193 \mathrm{~nm}$ excimer laser. The laser beam diameter was adjusted in the 60-90 $\mu \mathrm{m}$ range depending on phase dimensions. Background gas blanks were first measured on all masses for $40 \mathrm{~s}$ before laser ablation. Total laser firing time, which also depends on phase thickness, was up to $80 \mathrm{~s}$. Ca determined by electron microprobe was used as internal standard. The reference NIST 612 glass was used as primary calibration standard, while BCR-2 and BIR glasses were used as secondary standards. The precision of the LA-ICP-MS analytical technique was better than $10 \%$ for all measured elements except $\mathrm{Ti}$ and $\operatorname{Zr}(20 \%)$.

\section{Characterization of the spinel Iherzolite prior to the experiments}

To better understand the experimental results of our study, it is necessary to precisely document the mineralogy and geochemistry of the starting Iherzolite, before its reaction with the adakitic melt. For the sake of concision, we only present hereafter a summary of the main petrographic and geochemical features. A detailed characterization of the geochemistry of the PM18-2 spinel Iherzolite is available in the electronic supplement.

\subsection{Petrography}


As mentioned earlier, the Iherzolite used in this study (PM18-2) is a medium-grained protogranular spinel Iherzolite. Most of grain boundaries are smoothly curvilinear, sometimes straight. The only crystalline phases observed in this sample were olivine (72 vol\%, about 4 $\mathrm{mm}$ of average size), orthopyroxene (19 vol\%, $4 \mathrm{~mm})$, clinopyroxene ( $7 \mathrm{vol} \%, 1.5 \mathrm{~mm})$ and spinel (2 vol\%, $1 \mathrm{~mm}$ ). Modes were estimated from whole-rock and primary mineral chemistry. We did not detect the occurrence of sulfides and metasomatically introduced phases such as amphibole, phlogopite or apatite. However, melt percolation is evidenced by (i) the presence of a thin $(<10 \mu \mathrm{m})$ film of glass around some primary olivine grains (Supplementary Fig. S1a), (ii) the occasional formation of spongy rims (up to $100 \mu \mathrm{m}$ ) of secondary clinopyroxene around primary clinopyroxene (Fig. S1b,c), (iii) the rare development of a thin $(<20 \mu \mathrm{m})$ rim of sieve-textured secondary spinel around primary spinel (Fig. S1c). Melt reaction with primary orthopyroxene apparently produced veins of a microlitic assemblage of clinopyroxene, olivine and glass (Fig. S1d). Note that the presence of polymineralic clusters, which could have formed following the quenching of a melt produced by decompression melting of volatile-bearing phases, was not observed (e.g. Chazot et al., 1996; Shaw, 2009; Yaxley and Kamenetsky, 1999).

\subsection{Whole-rock and major element phase chemistry}

Gervasoni et al. (2012) described the major and trace element bulk composition of the PM182 spinel Iherzolite, together with that of other 24 mantle xenoliths from Laguna Timone in Pali Aike. In summary, relative to Primitive Mantle values, the spinel Iherzolite has low $\mathrm{Al}_{2} \mathrm{O}_{3}(2.2$ wt\%), $\mathrm{CaO}(1.4 \mathrm{wt} \%)$ and $\mathrm{TiO}_{2}(0.05 \mathrm{wt} \%)$ contents, high $\mathrm{MgO}$ (44 wt\%) contents, an elevated Mg\# of 0.915 and a low Ca/Al ratio (0.85). Major element compositions of PM18-2 minerals are given in Supplementary Table S1 and Table S2. Rim to core profiles indicate that grains 
are chemically homogeneous. Our data also show that distinct grains of the same phase have similar composition, whether they are primary or secondary in nature. Primary orthopyroxenes are all enstatite $\left(\mathrm{En}_{90} \mathrm{Fs}_{9} \mathrm{Wo}_{1}\right)$ with $\mathrm{Mg \#}$ of 0.91 . Olivine Fo contents are 0.90. Clinopyroxenes are diopsidic with Mg\# of 0.91. Overall, spinel composition falls in the Al-rich, Mg-rich end of the field defined for abyssal peridotites (Dick and Bullen, 1984). Primary spinels are characterized by $\mathrm{Mg \#}$ of 0.77 and $\mathrm{Cr} \#$ (molar $\mathrm{Cr} /(\mathrm{Cr}+\mathrm{Al}))$ of 0.18 . Sieve-textured secondary spinels are more Cr-rich with $\mathrm{Cr} \#$ of 0.26 and $\mathrm{Mg \#}$ of 0.79 . The composition of the intergranular glass varies within the sample depending on its position (Supplementary Table S3), making it difficult to constrain its exact origin (infiltration and posterior modification of the host basalt, decompression melting, slab-derived melts, etc.). Most of the glass measurements fall within the "tephrite-basanite" field in total alkali - silica nomenclature diagram of Le Bas and Streckeisen (1991).

\subsection{Equilibrium conditions, melt depletion and cryptic metasomatism}

Methods to estimate equilibrium conditions (temperature, pressure and oxygen fugacity) are detailed in the electronic supplement. Whole-rock and pyroxene major and trace element compositions of the spinel Iherzolite indicate that the degree of melt depletion was on the order of $10-15 \%$. Estimates of equilibrium temperature for the spinel Iherzolites are between $960-990^{\circ} \mathrm{C}$, while equilibrium pressure is in the 13.3-18.0 kbar range. The equilibrium oxygen fugacity is relatively low, at about FMQ-0.7. Moreover, the general enrichment in most incompatible trace elements observed in both whole-rock and clinopyroxene compositions indicate that the xenolith has experienced some degree of cryptic metasomatism. Relatively low Ti contents in mineral and whole-rock compositions and primitive-like Mg\# values suggest overall a moderate metasomatic contribution. Cryptic metasomatism in primary clinopyroxene 
is mostly evidenced by LREE enrichment. As detailed in the electronic supplement, the identity of the metasomatizing agent remains unresolved. This indicates that metasomatism was a complex process, possibly as a result of successive events involving distinct melts.

\section{Results}

As expected, changes in phase relations and chemistry occurred in the experimental charges. Given that the equilibrium conditions of the starting Iherzolite broadly correspond to the conditions selected for our experiments, the observed modifications should reflect the results of adakitic metasomatism. New minerals were formed in our experimental charges following two processes: (i) metasomatic reactions at the original peridotite-adakitic melt interface and within veins penetrating along grain boundaries near the interface due to reactive percolation; (ii) partial melting of the Cerro Pampa adakite, which led to the recrystallization of the initially fine powder. To distinguish between the minerals produced by metasomatism and those produced solely by crystallization of the adakite, we respectively use the suffixes "-M" and "-X" behind the mineral abbreviations (e.g Cpx-X, Opx-M, Sp-M). For primary minerals present in the experimental charges, we use the suffix "-P" (i.e. OI-P, Cpx-P, Sp-P, Opx-P). Some of the newly produced minerals occasionally show chemical disequilibrium, as evidenced by core-torim chemical zoning. Given that run durations were relatively long to promote equilibrium, chemical zoning is thought to be mostly a consequence of progressive change in the composition of the adakitic melt due to its continuing reaction with peridotite minerals (mostly olivine and spinel) at the interface and along grain boundaries. The representative average compositions of melts and mineral phases are presented in Table 3 and 4.

\subsection{Adakitic melts}


Melts produced in the experimental charges are subalkaline melts that range in composition from andesitic to dacitic $\left(60-66 \mathrm{wt} \% \mathrm{SiO}_{2}\right.$ on a water-free basis). Like the Cerro Pampa adakite, they have elevated Mg\# (>0.66) and therefore should not be considered as pristine slab melts but rather as "hybridized" slab melts that assimilated subcontinental mantle materials (e.g. Rapp et al., 1999).

\subsection{Metasomatic orthopyroxene}

As exemplified in Fig. 1a, we observed in all the experiments, with or without added water, the dissolution of olivine grains in contact with adakitic melt and formation of a 5-20 $\mu \mathrm{m}$ layer of metasomatic orthopyroxene (Opx-M) at the melt-primary olivine (OI-P) interface. Opx-M formed small euhedral crystals $2-5 \mu \mathrm{m}$ wide and elongated perpendicularly to the OI-P surface area. Major element composition of Opx-M was quite variable among the runs $\left(\mathrm{En}_{80-}\right.$ 96), while primary orthopyroxene (Opx-P), which appeared unaffected by the adakitic melt, was $\mathrm{En}_{90} \mathrm{Fs}_{9} \mathrm{Wo}_{1}$ (Table 3). As shown in Fig. 2, the En content of Opx-M primarily depends on the composition of the silicic melt (Mg\#), which varied among the runs due to distinct experimental conditions and also as a consequence of variable extents of chemical interactions with peridotite minerals (i.e. hybridization grade). Opx-M was closer to the enstatite end-member $\left(\mathrm{En}_{96} \mathrm{Fs}_{1} \mathrm{Wo}_{3}\right)$ when melt had higher $\mathrm{Mg \#}(0.98)$, while it tended toward

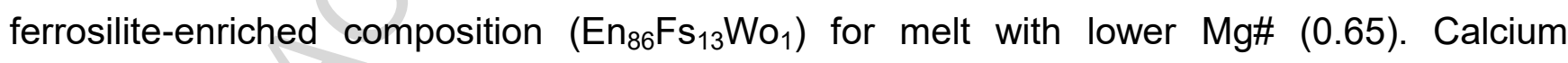
contents of Opx-M did not vary much $\left(\mathrm{Wo}_{1-3}\right)$. Compared to primary orthopyroxene, metasomatic orthopyroxene had similar $\mathrm{Al}_{2} \mathrm{O}_{3}$ contents, higher $\mathrm{TiO}_{2}$ contents (about $0.2 \mathrm{wt} \%$ ) and much lower $\mathrm{Cr}_{2} \mathrm{O}_{3}$ contents (<0.12 wt\%) (Table 3). No major core-to-rim chemical zoning ( $\mathrm{Mg}, \mathrm{Fe}, \mathrm{Ni}$, etc.) was detected in primary olivine affected by the metasomatic Opx-M formingreaction. Only in runs \#123 and \#124 where the melt had high Mg\#, the presence of a thin $(<3$ 
$\mu \mathrm{m})$ rim enriched in forsterite component (Fo93-94) was observed around primary olivine. No fayalite-rich rim formed in runs with low Mg\#.

\subsection{Metasomatic spinel}

In runs with spinel present at or near the peridotite-adakite interface (run \#124 and \#128, and also in run \#125 to a limited extent), secondary metasomatic spinel ( $\mathrm{Sp}-\mathrm{M})$ formed as sievetextured rims of primary spinel (Fig. 1b). There is no discernable reaction zone around primary spinel grains located away from the interface except when infiltrated melt is present. $\mathrm{Sp}-\mathrm{M}$ is enriched in $\mathrm{Cr}$ and depleted in $\mathrm{Al}$ and $\mathrm{Fe}\left(\mathrm{Fe}^{2+}\right.$ and $\left.\mathrm{Fe}^{3+}\right)$ in comparison with the primary spinel $(\mathrm{Sp}-\mathrm{P})$. The $\mathrm{Cr}$-number $(\mathrm{Cr} \#=\mathrm{Cr} /(\mathrm{Cr}+\mathrm{Al})$ in mole fractions $)$ of $\mathrm{Sp}-\mathrm{M}$ averages 0.34 , while the $\mathrm{Mg}$-number $\left(\mathrm{Mg} \#=\mathrm{Mg}^{2+} /\left(\mathrm{Mg}^{2+}+\mathrm{Fe}^{2+}\right)\right.$ in mole fractions $)$ averages 0.81-0.82 (Table 4). This compares to lower values for primary spinel of $\mathrm{Cr} \#$ of $0.19-0.21$ and $\mathrm{Mg \#}$ of $0.77-0.78$. Interestingly, a detailed examination reveals a chemical gradient in Sp-M with composition becoming richer in $\mathrm{Cr}$ and $\mathrm{Fe}$ and poorer in $\mathrm{Mg}$ away from the primary spinel, i.e. toward the melt. This was particularly evident in run \#128, which exhibits the thickest $\mathrm{Sp}-\mathrm{M}$ reaction rim. $\mathrm{Cr} \#$ in this run ranges from 0.29 near $\mathrm{Sp}-\mathrm{P}$ to 0.45 near the melt, while $\mathrm{Mg \#}$ varied from 0.83 near Sp-P to 0.79 near the melt (Fig. 3). Moreover, a slight zoning was detectable in primary spinel, which upon reaction with the adakitic melt develops a thin Fe-poor, Mg-rich rim (Mg\# $=0.80$ versus 0.78 for the core) (Fig. 3).

\subsection{Metasomatic amphibole}

In runs with high contents of added water such as run \#125 and \#132 (about 9 and 12 wt\% $\mathrm{H}_{2} \mathrm{O}$ in quenched melt, respectively), the formation of metasomatic amphibole (Amp-M) was observed. They form anhedral to subhedral crystals up to $30 \mu \mathrm{m}$ in run \#125 and up to $80 \mu \mathrm{m}$ 
in run \#132 (Fig. 1C). A longer run duration (116 h against $40 \mathrm{~h}$ ), higher run temperature (1050 ${ }^{\circ} \mathrm{C}$ against $1000{ }^{\circ} \mathrm{C}$ ) and a higher water content may have favored the growth of larger amphibole crystals in run \#132 compared to run \#125. In both runs, amphibole crystals formed in areas of melt infiltration along primary clinopyroxene grain boundaries (Fig. 1c). In run \#125 the boundary was shared with primary spinel, whereas it seemed to be solely with primary olivine in run \#132. The composition of Amp-M was similar in the two runs and lies in the pargasite field of calcic amphiboles as defined by Hawthorne et al. (2012). Minor differences were observed in the $\mathrm{TiO}_{2}, \mathrm{Al}_{2} \mathrm{O}_{3}$ and $\mathrm{Cr}_{2} \mathrm{O}_{3}$ contents between both runs, with slightly higher contents $(1.5,14.4$ and $1.6 \mathrm{wt} \%$, respectively) for run \#125 and lower contents $(1.2,13.4$ and $0.8 \mathrm{wt} \%$, respectively) for run \#132 (Table 3).

\section{5. "Secondary" minerals formed by crystallization of the adakite component}

The crystallization of Ti-rich, $\mathrm{Cr}$ - and Na-poor clinopyroxene (Cpx-X), mostly as euhedral crystals, was observed in all runs (see for example Fig. 1a and Fig. 1d), except in run \#123. The overall preservation of primary clinopyroxene - adakite interface prescribes the formation of this secondary clinopyroxene from primary clinopyroxene (Fig. 1d). Rather, its presence within the adakitic part of the experimental charge and along the melt-peridotite interface independently of the nature of the exposed peridotite minerals - most likely results from solidstate recrystallization of the adakite powder or crystallization from the partially molten adakite. It would not be related to a metasomatic reaction involving mantle minerals. The absence of this secondary clinopyroxene from run $\# 123$, which was performed at the highest experimental temperature $\left(1300^{\circ} \mathrm{C}\right)$, could be explained by prevailing conditions above the adakite liquidus. In most cases, $\mathrm{Cpx}-\mathrm{X}$ is diopsidic $\left(\mathrm{En}_{45-53} \mathrm{Fs}_{4-10} \mathrm{Wo}_{42-46}\right)$ similar to the primary clinopyroxene $\left(\mathrm{En}_{49} \mathrm{Fs}_{5} \mathrm{Wo}_{46}\right)$, except in the anhydrous run $\# 120$ where it lies in the augite 
field $\left(\mathrm{En}_{61} \mathrm{Fs}_{4} \mathrm{Wo}_{35}\right)$ (Table 3). The latter is due to the relatively high temperature of run $\# 120$ $\left(1250^{\circ} \mathrm{C}\right)$, since $\mathrm{Cpx}$ are known to become more augitic at higher temperature (e.g. Lindsley, 1983). As shown in Table 3, $\mathrm{Na}_{2} \mathrm{O}$ and $\mathrm{Cr}_{2} \mathrm{O}_{3}$ contents of $\mathrm{Cpx}-\mathrm{X}(0.8-0.9 \mathrm{wt} \%$ and $<0.4 \mathrm{wt} \%$, respectively) were lower than those of primary clinopyroxene (in the ranges $1.2-1.4 \mathrm{wt} \%$ and 0.8-0.9 wt\%, respectively). $\mathrm{TiO}_{2}$ contents were however higher, usually on the order of 0.3-0.5 wt\% (compared to 0.2 wt\% in Cpx-P), and up to 0.9 wt\% in run \#125. Some of the Cpx-X crystals in run \#120, \#124 and \#132 had Fe-enriched core. In addition, a chemical gradient was also observed in these runs. Cpx-X crystals closer to the peridotite interface are slightly poorer in jadeite components $\mathrm{Na}$ and $\mathrm{Al}$. Given that these runs were the ones with the longest duration, this may suggest that these chemical heterogeneities were generated as a result of continuous change in the composition of the adakitic melt due to the progressive reaction with peridotite minerals. In addition, some loss of $\mathrm{Fe}$ to the Pt capsule may have promoted zoning in $\mathrm{Fe}$.

Run \#132 produced Cpx-X crystals sufficiently large to perform trace element measurements by LA-ICP-MS. Corresponding trace element patterns are shown in Figure 4 and compared to that of primary clinopyroxene and adakitic melt. The former displays a rather flat REE pattern, while the latter displays an enriched LREE pattern inherited from the original natural adakite from Cerro Pampa used in the experiment. As discussed by Rapp et al. (1999), mantle assimilation is not expected to generate significant trace element fractionation in hybridized adakite magmas. This is verified in Fig. 4, which shows similarities between the trace element abundance patterns of both the reacting and pristine melts. Crystallization of the adakite produces a secondary clinopyroxene with MREE-enrichment relative to primary clinopyroxene, but with similar La and lower Lu content. Lattice strain effects probably explain 
the limited incorporation of LREE in secondary clinopyroxene (Blundy et al., 1998). In comparison with primary clinopyroxene, secondary clinopyroxene also had lower $\mathrm{Nb}, \mathrm{Ta}, \mathrm{U}$ and Th contents but higher $\mathrm{Sr}, \mathrm{Ba}$ and $\mathrm{Rb}$ contents.

In addition to secondary Cpx-X, runs \#120 and \#125 also produced plagioclase crystals (Plag-X) dispersed along the interface and within the adakitic portion of the experimental charge. Average composition lies in the andesine field ranging between $\mathrm{An}_{36}$ (run \#120) and $\mathrm{An}_{48}$ (run \# 125) depending on run conditions (Fig. 1e). This is coherent with the observation that plagioclase composition is more enriched in the An component in hydrous systems (Housh and Luhr, 1991). Slight normal zoning was evident in run \#125 with core of about $A n_{50}$ and a $5 \mu \mathrm{m}$ thick rim of $\mathrm{An}_{40}$.

In the low temperature run $\# 125\left(1000^{\circ} \mathrm{C}\right)$, the crystallization of orthopyroxene (Opx-X) within the adakitic portion of the experimental charge was also detected (Fig. 1e). Considering textural criteria, we interpreted its formation as a low temperature crystallization product of the adakite rather than the product of a metasomatic reaction (i.e. like for $\mathrm{Cpx}-\mathrm{X}$ and Plag-X). Opx-X had an average composition of $\mathrm{En}_{81} \mathrm{Fs}_{17} \mathrm{Wo}_{2}$, which means that it was significantly more enriched in Fe compared to Opx-P and Opx-M (Table 3).

\subsection{Preservation of primary clinopyroxene and orthopyroxene.}

As shown in Fig. 1d and Fig. 1f, primary orthopyroxene and clinopyroxene exposed at the interface did not show evidence of a chemical reaction with the adakitic melt (reaction rim or partial dissolution). This contrasts to what has been observed for primary spinel and primary olivine and relates to the siliceous nature of the melts $\left(56-65 \mathrm{wt} \% \mathrm{SiO}_{2}\right)$. It also contrasts with 
the reaction features of primary orthopyroxene $(\mathrm{Opx} 1)$ and primary clinopyroxene $(\mathrm{Cpx} 1)$ documented in the starting Iherzolite xenolith prior to perform the experiments (see supplementary Fig. S1). Cpx1 and Opx1 were both occasionally affected by melt percolation generating respectively rims of secondary clinopyroxene $(\mathrm{Cp} \times 2)$ and rims of a microlitic assemblage of secondary clinopyroxene (Cpx3), olivine (OI2) and glass. This was most likely related to the infiltration of a silica-undersaturated melt such as the host basalt (see discussion in electronic supplement).

\section{Discussion}

\subsection{Comparison with previous experimental studies}

Experiments simulating the interaction between subalkaline siliceous melts and peridotite at mantle wedge conditions are limited. Most of the experimental work published so far has focused on silica-undersaturated melts. Furthermore, previous experimental works did not use cored peridotite samples, but fine-grained powders of synthetic or natural mixtures or mineral separates. As discussed by Arai and Kida (2000) among other authors, fine-grained equigranular peridotites extracted from the mantle probably formed from coarser ones following recrystallization assisted by slab-derived melts or fluids. Considering that partial melting tends to transform the original coarse-grained equigranular texture of pristine peridotite into a medium-grained protogranular texture (e.g. Mercier and Nicolas, 1975), we selected as starting material a spinel Iherzolite with the latter textural type as representative of the unmetasomatized depleted mantle wedge. From a textural point of view, the experimental simulations performed in this study would more accurately simulate natural conditions than previous ones. As summarized below, previous experimental works span a range of pressure and temperature conditions relevant to the mantle wedge $\left(1.0-3.8 \mathrm{GPa}, 900-1100^{\circ} \mathrm{C}\right)$, as well 
as a range of slab-derived melt compositions, which would represent distinct degrees of hybridization.

Sen and Dunn (1994) reported results of siliceous melt infiltration experiments at 1.5 and 2.0 GPa using a layer of powdered spinel Iherzolite juxtaposed to a layer of powdered amphibolite. Partial melts of the amphibolite represent an analog of pristine slab-derived melts (61-68 wt\% $\mathrm{SiO}_{2}$, Mg\# 0.30-0.35, 4-9 wt\% $\mathrm{H}_{2} \mathrm{O}$ ). Rapp et al. (1999) also reported results of slab melting and mantle assimilation experiments at $3.8 \mathrm{GPa}$ and $1100{ }^{\circ} \mathrm{C}$ using powders of natural amphibolitized basalt in contact with either depleted or fertile peridotite powders. Produced melts are dacitic-trachydacitic melts $\left(61-68 \mathrm{wt} \% \mathrm{SiO}_{2}\right)$ with relatively low $\mathrm{Mg \#}(0.44-$ 0.56) and about $10 w t \% \mathrm{H}_{2} \mathrm{O}$. The work of Rapp et al. (1999) agreed with and extended the earlier works by Sekine and Wyllie (1982a, 1982b) and Johnston and Wyllie (1989) at 3 GPa in the granite-peridotite- $\mathrm{H}_{2} \mathrm{O}$ and tonalite-peridotite- $\mathrm{H}_{2} \mathrm{O}$ systems. Prouteau et al. (2001) reported experimental results obtained at $1.5 \mathrm{GPa}$ and $900-1000{ }^{\circ} \mathrm{C}$ on the interaction between $\mathrm{Fo}_{90}$ olivine separates and hydrous trondhjemitic melts (64-66 wt\% $\mathrm{SiO}_{2}$ and relatively high Mg\# 0.7-0.85). Prouteau and Scaillet (2003) presented additional experimental work at $920 \mathrm{MPa}$ and $950-1000{ }^{\circ} \mathrm{C}$ on the interaction between dacitic melts $\left(70 \mathrm{wt} \% \mathrm{SiO}_{2}\right.$ and

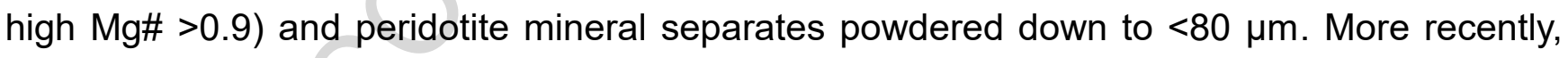
Gervasoni et al. (2017) reported experimental results on the interaction between hydrous eclogite-derived melts and peridotite at 2.2-2.5 $\mathrm{GPa}$ and $900-1000{ }^{\circ} \mathrm{C}$ using synthetic powdered mixtures as starting materials. The produced partial melts were andesitic to dacitic (on a water-free basis) with Mg\# between 0.4 and 0.7 . 
In agreement with our observations for low Mg\# melts, Sen and Dunn (1994) reported the formation of Fe-enriched metasomatic orthopyroxene $\left(E n_{74-84}\right)$ as a rim on primary olivine (Fogo) exposed at the interface between peridotite and the partially melted amphibolite. They also observed the formation of slightly Fe-rich metasomatic orthopyroxene $\left(\mathrm{En}_{87-90}\right)$ at the rim of primary orthopyroxene $\left(E n_{90}\right)$ and along primary olivine-olivine, olivine-clinopyroxene and olivine-spinel grain boundaries. The formation of metasomatic orthopyroxene at the rim of primary orthopyroxene was not observed in our study. As shown in Fig. 1f, the formation of a rim of metasomatic orthopyroxene only occurred in contact with primary olivine. Furthermore, Sen and Dunn (1994) reported the formation of a thin $(<3 \mu \mathrm{m})$ layer of Ca-, Al-, Fe-enriched secondary olivine $\left(\mathrm{Fo}_{80-82}\right)$ on primary olivine $\left(\mathrm{Fo}_{90}\right)$. We did not observe such a rim in our runs where primary olivine was in contact with low Mg\# melt (\#125, \#132). In contrast, in runs with high Mg\# melt, we observed the occurrence of a $\mu \mathrm{m}$ thin rim of Fo-enriched olivine (Fo9394) in contact with metasomatic orthopyroxene (Mg\# 0.96-0.99) (see for example run \#124 in Fig. 1a). Sen and Dunn (1994) also reported the formation of rims of secondary clinopyroxene on primary clinopyroxene with variable compositions depending on whether the grain boundary was shared with metasomatic amphibole or orthopyroxene. Formation of metasomatic clinopyroxene whether in contact with amphibole or orthopyroxene was not observed in the current study. Similar to our results, Sen and Dunn (1994) found that secondary spinel were enriched in $\mathrm{Cr}$ and depleted in $\mathrm{Al}$ (high $\mathrm{Cr} \#$ ) compared to primary spinel. However, they reported a slight depletion in Mg, which we did not observe. Inversely, they reported no change in Fe content, which contrasts with our findings that secondary spinel is slightly depleted in Fe, leading to larger Mg\# than in primary spinel (Fig. 3). Such a discrepancy is likely related to the distinct melt compositions (Mg\#) obtained in the two studies. Agreement is shared however regarding the negative correlation between $\mathrm{Mg \#}$ and 
Cr\# of metasomatic spinel (Fig. 3). Sen and Dunn (1994) also reported the formation of amphibole at grain boundaries of primary olivine with clinopyroxene, spinel and to a lesser extent orthopyroxene. Our results indicate that the formation of amphibole was only observed at clinopyroxene-olivine and clinopyroxene-spinel grain boundaries (e.g. Fig. 1c). In agreement with our results, the amphiboles produced in the study of Sen and Dunn (1994) are calcic amphiboles (essentially pargasite and Mg-hastingsite, and in one occurrence Mghornblende) (Fig. 5). Other chemical considerations such as $\mathrm{Ca}, \mathrm{Mg}$ and Fe contents of the calcic amphiboles produced in our study and that of Sen and Dunn (1994) also approximate the compositional range observed in mantle wedge samples (Fig. 6). Amphiboles produced in the experiments of Sen and Dunn (1994) at grain boundaries between olivine, orthopyroxene and clinopyroxene lie outside the suprasubduction field (Fig. 6). They are slightly enriched in $\mathrm{Si}$ and $\mathrm{Mg}$ and depleted in $\mathrm{Ca}$ in comparison to the remaining amphiboles and the ones produced in our study.

Rapp et al. (1999) found that secondary clinopyroxene only appears as a residue of melting of eclogite, with a less jadeitic composition near the reaction zone. This is similar to what we observe for $\mathrm{Cpx}-\mathrm{X}$, which is interpreted as a crystallization product of the adakite component. They also reported that secondary metasomatic orthopyroxene formed as a result of melt interaction with the peridotite. Rapp et al. (1999) reported that their composition was enriched in $\mathrm{Ca}, \mathrm{Al}$ and $\mathrm{Fe}$ (low $\mathrm{Mg \# )}$ compared to that of primary orthopyroxene. Although Opx-M in our study was enriched in Ca compared to Opx-P, it had a similar Al content and variable Mg\# and Fe content depending on melt composition. Sen and Dunn (1994) also reported similar Al-rich contents (4-5 wt $\left.\% \mathrm{Al}_{2} \mathrm{O}_{3}\right)$ in primary and metasomatic orthopyroxenes, which was also observed in the results of our study. As shown in Fig. 2, Fe enriched Opx-M is expected at 
low melt Mg\#, which would then agree with the results of Rapp et al. (1999). The discrepancy in Al content is probably not linked to the metasomatic reaction, but rather relates to the difference in Al content of primary orthopyroxene, as discussed below. Finally, Rapp et al. (1999) interpreted the crystallization of Al-poor, Na- and K-rich amphibole (K-richterite) in the reaction zone as a product of melt-peridotite interactions. Such an amphibole composition contrasts with that of the calcic amphiboles produced in our experiments and in the study of Sen and Dunn (1994), the latter composition being more representative of natural amphiboles of subduction-related environments (Fig. 6).

As in previous studies, Prouteau et al. (2001) observed the formation of secondary orthopyroxene $\left(\mathrm{En}_{93} \mathrm{Fs}_{5} \mathrm{Wo}_{2}\right)$ at $1000{ }^{\circ} \mathrm{C}$ and secondary orthopyroxene $\left(\mathrm{En}_{89} \mathrm{Fs}_{9} \mathrm{Wo}_{2}\right)$, amphibole and phlogopite at $900{ }^{\circ} \mathrm{C}$. Similarly to our results (see Fig. 2), the Mg\# of orthopyroxene (0.94 and 0.91 at 1000 and $900{ }^{\circ} \mathrm{C}$, respectively) correlates with the $\mathrm{Mg \#}$ of the residual dacitic melts (0.84 and 0.71 at 1000 and $900^{\circ} \mathrm{C}$, respectively). Like in Rapp et al. (1999), the amphibole produced by Prouteau et al. (2001) was a Na-Ca amphibole (katophorite), owing to the Na-rich nature of the interacting melts (9-11 wt $\left.\% \mathrm{Na}_{2} \mathrm{O}\right)$. Phlogopite was also present at $900^{\circ} \mathrm{C}$, which may be linked to the specific melt composition and, as discussed by Rapp et al. (1999), to a relatively low melt/rock ratio.

In the study of Prouteau and Scaillet (2003), the interaction between dacitic melts and mantle mineral separates (olivine \pm orthopyroxene \pm clinopyroxene) produced secondary orthopyroxene, calcic amphibole, as well as phlogopite in one run where solely olivine was reacted with the dacite. The composition of metasomatic orthopyroxene was quite variable within a single run. It contains a fair amount of $\mathrm{Al}\left(2-5 \mathrm{wt} \% \mathrm{Al}_{2} \mathrm{O}_{3}\right)$. It was either Fe- or Mg- 
enriched $\left(\mathrm{En}_{82-95} \mathrm{Fs}_{5-16} \mathrm{Wo}_{1-3}\right)$ compared to primary orthopyroxene $\left(\mathrm{En}_{88}\right)$. Their composition does not relate clearly to the melt Mg\#. Unfortunately, Prouteau and Scaillet (2003) do not present a description of the sample texture to constrain the origin of these chemical variations. The calcic amphiboles are mostly pargasitic as shown in Fig. 5. They are more Mgand Fe-rich than natural calcic amphiboles found in suprasubduction settings, as well as the ones produced experimentally in our study and that of Sen and Dunn (1994) (Fig. 6). Considering that phlogopite is Al-rich and Na-rich, its production in one of the runs was probably related to some extent to the elevated $\mathrm{Al}$, alkali and water contents of the metasomatizing melt used in their study.

Gervasoni et al. (2017) reported the formation of mainly Al-rich orthopyroxene (4-5 wt $\% \mathrm{Al}_{2} \mathrm{O}_{3}$ ) and amphibole in the reaction zone between partially molten eclogite and peridotite. We agree with Gervasoni et al. (2017) that the crystallization of Al-rich metasomatic orthopyroxene observed in all experimental studies mentioned above is linked to the Al-rich nature of the siliceous melts reacting with primary olivine. The elevated Al content of secondary orthopyroxene could thus be a useful chemical tracer of Al-, Si-rich slab-derived melts. Amphiboles produced in the experiments of Gervasoni et al. (2017) were quite variable in composition and include pargasite, Mg-hastingsite, Mg-hornblende and sadanagite (Fig. 5). Similarly to those produced in the study of Prouteau and Scaillet (2003), these amphiboles tend to be either more Mg-rich or Fe-rich than natural amphiboles found in suprasubduction settings and those produced experimentally in this study and that of Sen and Dunn (1994) (Fig. 6).

5.2. Forming reactions of metasomatic orthopyroxene, amphibole and spinel 
The results of this study pinpoint three main metasomatic reactions related to the infiltration of adakitic melts: orthopyroxene-forming reaction at primary olivine boundaries, spinel-forming reaction at primary spinel boundaries and amphibole-forming reaction in veins where the melt is in contact with primary clinopyroxene.

There is a consensus in the literature that secondary orthopyroxene is formed at the expense of primary olivine following an incongruent dissolution reaction of the type: OI-P + Liqinitial $=$

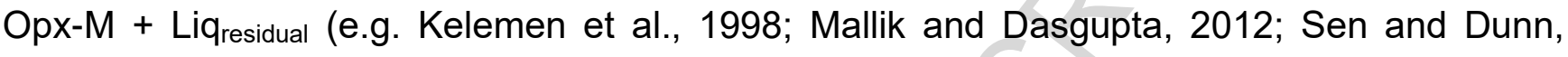
1994). During the reaction, $\mathrm{SiO}_{2}, \mathrm{CaO}, \mathrm{Al}_{2} \mathrm{O}_{3}$ and $\mathrm{TiO}_{2}$ are extracted from the melt to generate secondary orthopyroxene enriched in $\mathrm{Ca}, \mathrm{Ti}$ and $\mathrm{Al}$ as reported in Table 3:

$\mathrm{SiO}_{2}$ Liq $+\mathrm{Mg}_{2} \mathrm{SiO}_{4}$ OI-P $=\mathrm{Mg}_{2} \mathrm{Si}_{2} \mathrm{O}_{6}$ Opx-M

$\mathrm{CaO} \mathrm{Liq}+2 \mathrm{Mg}_{2} \mathrm{SiO}_{4}$ OI-P $=\mathrm{CaMgSi}_{2} \mathrm{O}_{6}$ Opx-M $+3 \mathrm{MgO}_{\text {Liq }}$

$\mathrm{Al}_{2} \mathrm{O}_{3} \mathrm{Liq}_{2}+\mathrm{Mg}_{2} \mathrm{SiO}_{4}$ Ol-P $=\mathrm{MgAl}_{2} \mathrm{SiO}_{6}$ Opx-M $+\mathrm{MgO}_{\text {Liq }}$

$\mathrm{TiO}_{2} \mathrm{Liq}+\mathrm{Al}_{2} \mathrm{O}_{3} \mathrm{Liq}+0.5 \mathrm{Mg}_{2} \mathrm{SiO}_{4}$ OI-P $=\mathrm{MgAl}_{2} \mathrm{TiO}_{6}$ Opx-M $+0.5 \mathrm{SiO}_{2}$ Liq

Secondary spinel with high $\mathrm{Cr} \#$ (enriched in $\mathrm{Cr}$ and depleted in Al) compared to primary spinel have also been reported in the literature as a product of incongruent reactions affecting primary spinel, either of reaction-replacement origin or either of partial melting origin (e.g. Dick and Bullen, 1984; Kilian and Stern, 2002; Neal, 1988; Sen and Dunn, 1994; Shaw et al., 2006). In our experiments, several evidences support that the sieve-textured secondary spinel was formed following reactionary replacement of primary spinel rather than partial melting: (i) the lack of correlation between run temperature and $\mathrm{Cr} \#$ values (Table 4) (ii) the lack of correlation between run temperature and the size of secondary spinel rims (Table 2), (iii) textural observations of rapid 'skeletal' growth of secondary spinel in place of primary spinel 
preserving the general shape of the initial primary spinel-melt interface (Fig. 1b). As discussed by Shaw and Dingwell (2008) and in agreement with our observations, the sieve texture would thus initiate with the dissolution of primary spinel, followed by nucleation and subsequent growth of secondary spinel at the melt-primary spinel interface. The chemical gradient recorded in the sieve textured spinel rim, with higher $\mathrm{Cr} \#$ toward the melt and lower Cr\# toward primary spinel (Fig. 3), can be explained by the fact that $\mathrm{Cr}$ diffusion in spinel is about one order of magnitude slower than that of Al (Suzuki et al., 2008). Primary spinel dissolution would thus release more readily $\mathrm{Al}$ than $\mathrm{Cr}$ to the melt. As time proceeds, the residual secondary spinel most exposed to the melt would become more Cr-rich. The overall replacement of primary spinel by secondary spinel would be associated with the partial loss of the low temperature-fast diffusive component $\left(\mathrm{FeAl}_{2} \mathrm{O}_{4}\right)$ to the adakitic melt, leading to high Cr\# and Mg\# secondary spinel (Fig. 3). The dissolution process would therefore involve twostep reactions in the form of:

$$
\begin{aligned}
& 2 \mathrm{MgAICrO}_{4} \text { Sp-P }=2 \mathrm{MgO}_{\text {Liq }}+\mathrm{Al}_{2} \mathrm{O}_{3} \text { Liq }+\mathrm{Cr}_{2} \mathrm{O}_{3} \text { Liq } \\
& =\mathrm{MgCr}_{2} \mathrm{O}_{4} \text { Sp-M }+\mathrm{Al}_{2} \mathrm{O}_{3} \text { Liq }+\mathrm{MgO}_{\text {Liq }} \\
& \begin{aligned}
\left(\mathrm{Fe}^{2+}{ }_{1-\mathrm{x}} \mathrm{Mg}_{\mathrm{x}}\right) \mathrm{Al}_{2} \mathrm{O}_{4} \text { Sp-P }= & (1-\mathrm{x}) \mathrm{FeO}_{\text {Liq }}+\mathrm{x} \mathrm{MgO} \text { Liq } \\
& =\mathrm{Al}_{2} \mathrm{O}_{3} \text { Liq } \\
& =\mathrm{MgAl}_{2} \mathrm{O}_{4} \text { Sp-M }+(1-\mathrm{x}) \mathrm{Al}_{2} \mathrm{O}_{3} \text { Liq }+(1-\mathrm{x}) \mathrm{FeO}_{\text {Liq }}
\end{aligned}
\end{aligned}
$$

Although the experimental results obtained by Prouteau and coworkers (Prouteau et al., 2001; Prouteau and Scaillet, 2003) indicate that it is possible to produce calcic amphibole in the absence of clinopyroxene under specific hydrous melt composition, the formation of amphibole in metasomatized mantle xenoliths has been largely linked to melt-clinopyroxene reaction based on petrological considerations (e.g. Coltorti et al., 2004; Neal, 1988; Sen and Dunn, 1994). Depending on the composition of the metasomatic agent, the formation of 
amphibole could be associated with the precipitation of olivine and/or $\mathrm{Cr}$-rich spinel (Francis, 1976; Neal, 1988). In the case of a Na-alkaline high-Ti mafic silicate melt, Mg-rich olivine and Cr-rich spinel would crystallize alongside amphibole (Coltorti et al., 2004). In the case of a Sirich melt, secondary orthopyroxene would be expected to be present with amphibole (Prouteau et al., 2001; Prouteau and Scaillet, 2003; Rapp et al., 1999; Sen and Dunn, 1994). In our results, amphibole formed along clinopyroxene-olivine (run \#132) and clinopyroxenespinel (run \#125) grain boundaries. Interestingly, amphibole did not form at the clinopyroxeneadakitic melt interface. Given that the composition of the infiltrated melt is not significantly different from that of the main melt batch present at the interface, the amphibole formingreaction may require the involvement of melt, clinopyroxene and at least an additional mineral as reactants. Sen and Dunn (1994) proposed a reaction in which reactants were Si-rich melt and all primary minerals and products were pargasitic amphibole and secondary orthopyroxene. This reaction may correspond to what we observed in run \#132 within the vein infiltrating primary clinopyroxene-olivine grain boundaries, where amphibole coexists with secondary orthopyroxene (Fig. 1c). However, it is difficult to reconcile such a reaction with the other occurrence of amphibole at spinel-clinopyroxene grain boundaries (run \#125), as no coexisting secondary orthopyroxene was detected in the immediate vicinity. Interestingly, as shown in Table 3, amphibole compositions were quite comparable in both cases suggesting that a reaction involving the same reactants and products may have taken place. One possibility is that secondary orthopyroxene actually coexists with amphibole in run \#125 but was not detected in the $2 \mathrm{D}$ cross section of the experimental charge. An alternative hypothesis is that the amphibole forming-reaction mostly involves clinopyroxene and melt as reactants and pargasite as product in the form:

$2 \mathrm{CaMgSi}_{2} \mathrm{O}_{6}(\mathrm{Cpx}-\mathrm{P})+2 \mathrm{SiO}_{2}(\mathrm{Liq})+0.5 \mathrm{Na}_{2} \mathrm{O}_{(\mathrm{Liq})}+2 \mathrm{MgO}_{(\mathrm{Liq})}$ 


$$
+1.5 \mathrm{Al}_{2} \mathrm{O}_{3} \text { (Liq) }+\mathrm{H}_{2} \mathrm{O}_{\text {(Liq) }}=\mathrm{NaCa}_{2} \mathrm{Mg}_{4} \mathrm{Al}_{3} \mathrm{Si}_{6} \mathrm{O}_{22}(\mathrm{OH})_{2} \text { (Amp-M) }
$$

In this case, secondary orthopyroxene observed next to amphibole in run \#132 would solely be a product of primary olivine metasomatism. This would explain why its composition is almost identical to the one of secondary orthopyroxene present as a replacement rim of primary olivine at the original peridotite-adakite boundary. The absence of amphibole at the interface of $\mathrm{Cpx}-\mathrm{P}$ and adakitic melt might possibly be related to less favorable conditions for its nucleation.

\subsection{Comparison with mantle wedge xenoliths metasomatized by slab-derived melts}

Our experimental results make a good test to examine some of the petrological evidences put forward to support modal metasomatism by adakitic / hybridized slab-derived melts in several suprasubduction settings. The following discussion focuses on mantle xenoliths hosted in arc lavas and near-arc lavas from the following localities: Cerro del Fraile (Argentina), Batan Island and Monglo (Luzon arc, Philippines), Lihir Island (Papa New Guinea), Avacha volcano and Valovayam volcanic field (Kamchatka), Megata, Kurose and On-yama volcanoes (Japan), Finero (Italia) and Nunivak Island (Alaska).

Regarding modal metasomatism, there is a general agreement that adakitic metasomatism leads to the formation of secondary amphibole and orthopyroxene. As shown in Fig. 5 and 6 , pargasitic amphiboles such as the ones produced in our experiments, and to a minor extent Mg-hastingsites and Mg-hornblendes, are typical of amphiboles found in mantle xenoliths from suprasubduction settings (Coltorti et al., 2007 and references therein). For example, pargasites were predominantly reported (alongside a minority of other calcic amphiboles) in xenoliths from suprasubduction localities such as the Luzon arc in the Philippines (Grégoire et 
al., 2008), Finero in the Italian Alps (Zanetti et al., 1999), Cerro del Fraile in Argentina (Kilian and Stern, 2002; Wang et al., 2007), the Megata volcano of the Japan arc (Abe et al., 1998; Coltorti et al., 2007), the Kamchatka arc (Arai et al., 2003; Ishimaru et al., 2007; Kepezhinskas et al., 1995), the Lihir Island in Papua New Guinea (Grégoire et al., 2001) and the Nunivak Island in Alaska (Francis, 1976). Given their specific major and trace element geochemical signature, the occurrence of metasomatic amphiboles in these distinct localities has generally been linked to slab-derived fluids (e.g. Coltorti et al., 2007). The results of our experimental study provide strong support for this genetic relationship. Nonetheless, pargasites produced in our experiments and in Prouteau et al. (2001) are notably richer in $\mathrm{TiO}_{2}(1.1-1.7 \mathrm{wt} \%)$ than pargasitic amphiboles produced in other experiments and in many suprasubduction xenoliths (usually below $0.5 \mathrm{wt} \%$ ). This is directly linked to the relatively high Ti content of the metasomatizing melts used in our experiments and those of Prouteau et al. (2001). Since Kepezhinskas et al. (1995) and Coltorti et al. (2007) reported high $\mathrm{TiO}_{2}$ contents (1-3 wt\%) in amphiboles from Kamchatka, Japan and Austria mantle xenoliths, Ti-rich metasomatizing agents are probably occasionally involved, possibly due to a greater contribution of eclogitic materials to the generation of slab-derived melts (Coltorti et al., 2007).

Secondary metasomatic orthopyroxenes were reported in several of the localities where pargasitic amphiboles were found. For example, Faccini et al. (2013) described metasomatic orthopyroxene replacing olivine in peridotite xenoliths from Cerro del Fraile, Argentina. Fibrous, radiating secondary orthopyroxene aggregates and veins were also reported in mantle xenoliths from Papua New Guinea (Mclnnes et al., 2001), from Batan Island, Philippines (Arai et al., 2004), the Kamchatka arc (Arai et al., 2003; Ishimaru et al., 2007) and the Luzon arc (Grégoire et al., 2008). Such a peculiar texture of secondary orthopyroxene is 
similar to the one observed in this study (see Fig. 1a, Fig. 2). The major element compositions of metasomatic orthopyroxene reported in these studies are quite variable in terms of $\mathrm{Mg \# ,} \mathrm{Al,}$ $\mathrm{Ca}$ and $\mathrm{Cr}$ contents. It is therefore difficult to identify a specific chemical signature for secondary orthopyroxenes formed following slab-derived melt metasomatism. Their composition is ultimately linked to the composition of the interacting hydrous siliceous melt. For example, for the mantle wedge below the Philippines, Arai et al. (2004) and Grégoire et al. (2008) reported secondary orthopyroxene with high Mg content (Mg\#: 0.90-95), while Schiano et al. (1995) reported secondary orthopyroxene enriched in Fe (Mg\#: 0.86). In Cerro del Fraile, Argentina, Wang et al. (2007) also reported Fe-enriched (Mg\#: 0.86) orthopyroxene in intensely metasomatized fine-grained Iherzolites, which contrasts with the more Mg-rich composition (Mg\#: 0.91-0.92) of orthopyroxene in "unmetasomatized" coarse-grained peridotites. For the same locality, Faccini et al. (2013) also reported pyroxenites y websterites with $\mathrm{Mg \#}$ as low as 0.72 . Such a chemical variation probably correlates with variable $\mathrm{Mg \#}$ of the siliceous melts, which in turn will depend on whether the melts have been more or less hybridized by assimilation of mantle minerals. This process not only raises their $\mathrm{MgO}$ and

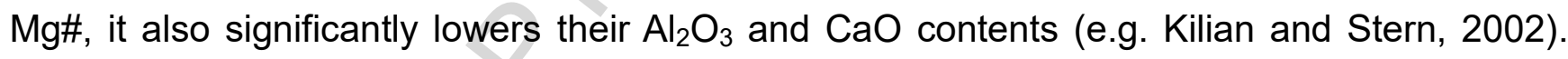
Overall, secondary orthopyroxene originated by putative slab-derived melts tends to have modest $\mathrm{CaO}$ and $\mathrm{Al}_{2} \mathrm{O}_{3}$ contents ( $<1$ and $<2$ wt\%, respectively) and low $\mathrm{Cr}_{2} \mathrm{O}_{3}$ and $\mathrm{TiO}_{2}$ contents ( $<0.5$ and $<0.1$ wt\%, respectively) (Arai et al., 2004, 2003; Grégoire et al., 2008; Ishimaru et al., 2007; Mclnnes et al., 2001; Schiano et al., 1995). Nonetheless, occurrences of Al-rich (3-5 ox\%), Ca-rich (>1 ox\%) and Ti-bearing (>0.1 ox\%) secondary orthopyroxenes, like the ones produced experimentally (Gervasoni et al., 2017; Prouteau and Scaillet, 2003; Sen and Dunn, 1994; This study), have been reported occasionally, for example in peridotites, 
pyroxenites and websterites from Cerro del Fraile and Kamchatka (Faccini et al., 2013; Kepezhinskas et al., 1995; Wang et al., 2007).

Surprisingly, among the dataset of natural samples described previously, there is almost no report of sieve-textured secondary spinel around primary spinel. Only Kilian and Stern (2002) mentioned the occurrence of corroded primary spinel surrounded by a rim of high-Cr spinel in Cerro del Fraile xenoliths. Despite this, metasomatic spinel in natural samples affected by putative slab-derived melt metasomatism has been shown to have elevated $\mathrm{Cr} \#$, as observed experimentally (Sen and Dunn, 1994; This study). Apart from the work of Kilian and Stern (2002), this has been well documented in metasomatized xenoliths from Batan Island, Philippines, where metasomatic spinel has Cr\# > 0.5 (Arai et al., 2004; Schiano et al., 1995). Furthermore, spinel in dunites from Monglo, Philippines, has rims systematically enriched in $\mathrm{Cr}(\mathrm{Cr} \#$ 0.4-0.6) and with lower Mg\# than the corresponding cores (Cr\# 0.3-0.4) (Grégoire et al., 2008). Spinel in metasomatized peridotites from Lihir, Papua New Guinea, also shows similar core-rim variations (Mclnnes et al., 2001). It has an overall higher $\mathrm{Cr} \#$ and lower $\mathrm{Mg \#}$ than spinel found in pristine peridotites from the same locality (Mclnnes et al., 2001). This trend, which is analogous to the one observed in this study (see Fig. 3), reflects dissolution of $\mathrm{Al}$ and oxidation of $\mathrm{Fe}^{2+}$ associated with metasomatism (Mclnnes et al., 2001; Shaw and Dingwell, 2008). Spinel in peridotite xenoliths from Avacha volcano, South Kamchatka, also displays high $\mathrm{Cr}$ contents ( $\mathrm{Cr} \#$ 0.5-0.7). Nonetheless, the high $\mathrm{Cr}$ contents would not relate to metasomatism but solely result from high degree partial melting induced by an influx of hydrous melt (Ishimaru et al., 2007). In some of the localities where slab-derived melt metasomatism has been invoked, metasomatic spinel also displays compositional variation significantly distinct from the aforementioned localities and experimental results (Sen and 
Dunn, 1994; This study). This is the case for Cerro del Fraile, Argentina, where metasomatic spinel was shown to have low $\mathrm{Cr} \#$ compared to more pristine spinel. Spinel in coarse-grained peridotites and pyroxenites displays a wide range of $\mathrm{Cr} \#(0.17-0.55)$, whereas spinel in finegrained Iherzolites has lower Cr\# (0.13) (Faccini et al., 2013; Wang et al., 2007). Metasomatism by a Si- and Al-rich melt was held responsible for the excess of $\mathrm{Al}$ in spinel in coarse-grained peridotite (Faccini et al., 2013). Kepezhinkas et al. (1995) also mentioned the presence of spinel with variable composition for utramafic xenoliths from the North Kamchatka arc, including metasomatic Al-Fe-Mg 'green' spinel with extremely low $\mathrm{Cr}(<1 \%)$. Again, enrichment in $\mathrm{Al}_{2} \mathrm{O}_{3}$ up 60 wt\% was ascribed to metasomatism by slab-derived melt. However, our experimental results and those of Sen and Dunn (1994) are at odds with these interpretations, since they show that metasomatic spinel tends to be depleted in Al following the interaction of peridotite with adakitic (Si- and Al-rich) melts (reaction 5).

The metasomatic precipitation of phlogopite and Ti-oxides has not been observed in our experimental run products or in those of Sen and Dunn (1994). These minerals are also lacking in xenoliths from the sub-Patagonian mantle beneath Cerro del Fraile (Faccini et al., 2013; Kilian and Stern, 2002; Wang et al., 2007). Conversely, rare to minor amounts of low Ti phlogopite have been reported in xenoliths from the Japan arc (Abe et al., 1998), from Batan Island and Monglo, Philippines (Arai et al., 2004; Grégoire et al., 2008; Schiano et al., 1995), from Lihir, Papua New Guinea (Mclnnes et al., 2001), and from the South Kamchatcka arc (Ishimaru et al., 2007). This suggests that alkali hydration reactions with mantle minerals (such as reaction 7) were able to produce phlogopite in addition to pargasitic amphibole. The reaction producing phlogopite would require elevated K-rich fluid-rock ratio, which explains the generally low abundance of phlogopite in metasomatic peridotites. Olivine would be a 
reactant alongside the K-rich fluid, while orthopyroxene would be a by-product (e.g. Schneider and Eggler, 1986). Mclnnes et al. (2001) and Kepezhinkas et al. (1995) were the only authors to report occurrences of Ti-oxides, respectively in association with $\mathrm{Fe}-\mathrm{Ni}$ sulfides in metasomatic veins and with green Al-Fe-Mg spinel. The first type of occurrences has been interpreted as a direct precipitate from the metasomatic fluid, while the second type has been linked to the breakdown of garnet and phlogopite (Kepezhinskas et al., 1995; McInnes et al., 2001). Bodinier et al. (1996) and Bedini and Bodinier (1999) observed the presence around spinel crystals of a thin reaction layer composed of $\mathrm{Ti}$ oxides and phlogopite in non-cratonic spinel Iherzolite xenoliths from the Ronda massif and the East African Rift. They interpreted this layer as a result of metasomatic process involving percolation of silica-rich and K-rich small melt fractions in the lithospheric mantle. They further conclude that this feature is likely present in most non-cratonic spinel Iherzolite xenoliths. We did not produce experimentally Tioxides or phlogopite layers around spinel from hydrous dacitic melts containing $1-2 \mathrm{wt} \% \mathrm{~K}_{2} \mathrm{O}$ and $12 \mathrm{wt} \% \mathrm{H}_{2} \mathrm{O}$. This suggests that a melt further enriched in $\mathrm{K}$ and other volatiles may be required to induce this metasomatic reaction. Its occurrence has neither been reported in the literature cited in this study to discuss metasomatism by slab-derived melts, nor, to our knowledge, in the Patagonian xenolith collection.

Secondary clinopyroxene has also been reported as a product of slab-derived melt metasomatism. Although we observed the crystallization of secondary diopsidic clinopyroxene $(\mathrm{Cpx}-\mathrm{X})$ in our experimental charges, we believe that it does not represent a true metasomatic product but rather a product from the crystallization of the adakite component. This would explain why the interface between primary clinopyroxene and the adakitic melt is neatly preserved (see section 4.6). Sen and Dunn (1994) however reported the formation of rims of 
secondary clinopyroxene on primary clinopyroxene with variable compositions depending on whether the grain boundary was shared with metasomatic amphibole or orthopyroxene. This true metasomatic reaction is most easily reconciled with a significant disequilibrium generated at low melt/rock ratio following spatiotemporal variations of melt composition in the experimental charges. Regarding natural xenolith samples, metasomatic secondary clinopyroxene has been reported for the Cerro del Fraile xenoliths. Kilian and Stern (2002) described, alongside dissolution of primary clinopyroxene, the formation of high- $\mathrm{Na}(>0.7$ wt\%) metasomatic clinopyroxene in Na-rich adakitic melt veins. Furthermore, Faccini et al. (2013) identified a variety of secondary clinopyroxenes depending on trace element contents and textural position. However, Wang et al. (2007) did not make any of these observations in an extended set of xenolith samples from Cerro del Fraile. Overall, this makes it difficult to identify a unique metasomatic event. A complex history involving other metasomatic agents in addition to slab-derived melts is most likely for the Cerro del Fraile sample suite. Kepezhinkas et al. (1995) also reported secondary clinopyroxene enriched in $\mathrm{Na}, \mathrm{Al}$ and $\mathrm{Fe}$ (Mg\#: 0.750.86) in xenoliths from the North Kamchatka arc, which they interpreted, in agreement with our observations, as a precipitation product of the adakitic (Na-, Al-, Fe-, Si-rich) melt. Finally, Mclnnes et al. (2001) observed high-Mg, low-Al secondary clinopyroxenes in metasomatized peridotites from Lihir, Papa New Guinea, which the authors interpreted as products of hydrous fluid metasomatism, involving dissolution of primary minerals and subsequent replacement by secondary minerals (mostly fibrous orthopyroxene and minor clinopyroxene).

\section{Conclusions}

We performed controlled high-pressure and high-temperature experiments to simulate the metasomatism of hybridized (adakitic) slab-derived melts on a depleted spinel Iherzolite 
representative of the mantle wedge. Reaction between the Si-, Al-rich melts and a natural depleted spinel Iherzolite of protogranular texture resulted in the formation of secondary orthopyroxene by incongruent dissolution of primary olivine. Our results combined with previous experimental works and petrological studies on mantle xenoliths suggest that the composition of secondary orthopyroxene, which is variable in terms of Mg\# and Al content for example, essentially depends on the composition of the metasomatic agent. Our experiments also indicate that adakitic metasomatism leads to the dissolution of primary spinel and subsequent replacement by secondary high-Cr spinel, forming characteristic sieve-textured rims on primary spinel. Modal metasomatism is also marked by the precipitation of pargasitic amphibole possibly at the expense of primary clinopyroxene when adakitic melt had high water content (ca. 9-12 wt\%). Primary clinopyroxene and primary orthopyroxene do not show signs of being significantly affected by adakitic metasomatism owing to the siliceous nature of the melts involved. Within the adakitic portion of the experimental charge, we also observed the precipitation of secondary $\mathrm{Ti}$-rich, $\mathrm{Cr}$ - and $\mathrm{Na}$-poor diopsidic clinopyroxene, andesine plagioclase and, in the low temperature run, Fe-enriched secondary orthopyroxene. Considering textural criteria, we interpreted the formation of these minerals as crystallization products of the adakite component and not as true products of metasomatic reactions with mantle minerals.

Thanks to the novel experimental approach followed in this study where a sample of natural spinel Iherzolite was cored to preserve the medium-grained protogranular texture relevant for the unmetasomatized depleted mantle wedge, we were able to discuss and refine previous experimental constraints. Given the specific composition of the adakitic melts produced in this study, we were also able to extend the effect of adakitic metasomatism to more Mg-rich 
compositions, which represent hybridized slab-derived melts that underwent further assimilation of mantle materials.

Our experimental results were finally used to examine some of the petrological evidences commonly presented to support modal metasomatism by slab-derived melts of mantle xenoliths extracted from several suprasubduction settings located around the Pacific Ring of Fire. As expected from the experimental results, the precipitation of pargasitic amphibole and secondary orthopyroxene was reported as characteristic of slab-derived metasomatism. Detailed variations in the amphibole and orthopyroxene compositions, such as the $\mathrm{Ti}, \mathrm{Al}, \mathrm{Ca}$

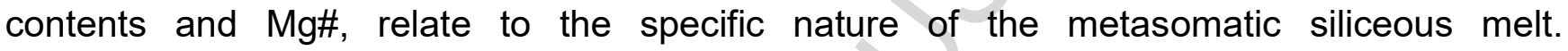
Interestingly, among the natural xenolith dataset, there is only one report of the occurrence of sieve-textured secondary spinel around primary spinel. From a chemical point of view, there are also some discrepancies, with some authors referring to high-Cr metasomatic spinel and others to high-Al metasomatic spinel, in both cases, as a consequence of interaction with Siand Al-rich slab-derived melts. Our experimental results support the former hypothesis. Other discrepancies with part of the reviewed xenolith dataset deal with the absence of phlogopite as a metasomatic precipitate in our experiments. We suggest that the phlogopite-producing reaction would require conditions that were apparently not reached in our experiments: a melt/fluid sufficiently enriched in $\mathrm{K}$ and water as well as an elevated fluid-rock ratio. 


\section{Acknowledgements}

The authors acknowledge financial support from the Chilean Fondecyt Regular Projects $n^{\circ}$ 1130635 (AC) and $n^{\circ} 1100724$ (MS) and administrative support from the Universidad Austral de Chile and the French National Center for Scientific Research (CNRS). Experimental facilities used in the study benefited from funding by the UnivEarthS Labex program at Sorbonne Paris Cité (ANR-10-LABX-0023 and ANR-11-IDEX-0005-02), the IPGP multidisciplinary program PARI, and the Region lle-de-France SESAME grant $n^{\circ} 12015908$. We acknowledge technical assistance from James Badro, Julien Siebert and Nicolas Wehr (Institut de Physique du Globe de Paris), and Claire Bassoullet (Institut Universitaire Européen de la Mer). The collection of the natural samples used in this study was made possible thanks to Rommulo Conceição (Universidade Federal do Rio Grande do Sul) and Yuji Orihashi (University of Tokyo). The final manuscript was improved by comments from two anonymous reviewers, the editor (Andrew Kerr) and Walter Brian Jones. 


\section{References}

Abe, N., Arai, S., Yurimoto, H., 1998. Geochemical characteristics of the uppermost mantle beneath the Japan island arcs: implications for upper mantle evolution. Phys. Earth Planet. Inter. 107, 233-248. doi:10.1016/S0031-9201(97)00136-2

Arai, S., Ishimaru, S., 2008. Insights into petrological characteristics of the lithosphere of mantle wedge beneath arcs through peridotite xenoliths: A review, Journal of Petrology. doi:10.1093/petrology/egm069

Arai, S., Ishimaru, S., Okrugin, V.M., 2003. Metasomatized hazburgite xenoliths from Avacha volcano as fragments of mantle wedge of the Kamchatka arc: Implication for the metasomatic agent. IsI. Arc 12, 233-246. doi:10.1046/j.1440-1738.2003.00392.x

Arai, S., Kida, M., 2000. Origin of fine-grained peridotite xenoliths form Iraya volcano of Batan Island, Philippines: Deserpentinization or metasomatism at the wedge mantle beneath an incipient arc? Isl. Arc 9, 458-471. doi:10.1111/j.1440-1738.2000.00294.x

Arai, S., Takada, S., Michibayashi, K., Kida, M., 2004. Petrology of peridotite xenoliths from Iraya volcano, Philippines, and its implication for dynamic mantle-wedge processes. J. Petrol. 45, 369-389. doi:10.1093/petrology/egg100

Bedini, R.M., Bodinier, J.-L., 1999. Distribution of incompatible trace elements between the constituents of spinel peridotite xenoliths: ICP-MS data from the East African rift. Geochim. Cosmochim. Acta 63, 3883-3900. doi:10.1016/s0016-7037(99)00154-4

Bjerg, E.A., Ntaflos, T., Thöni, M., Aliani, P., Labudia, C.H., 2009. Heterogeneous lithospheric mantle beneath Northern Patagonia: Evidence from Prahuaniyeu garnet- and spinelperidotites. J. Petrol. 50, 1267-1298. doi:10.1093/petrology/egp021

Blundy, J.D., Robinson, J.A.C., Wood, B.J., 1998. Heavy REE are compatible in clinopyroxene on the spinel Iherzolite solidus. Earth Planet. Sci. Lett. 160, 493-504. 
Bodinier, J.L., Merlet, C., Bedini, R.M., Simien, F., Remaidi, M., Garrido, C.J., 1996.

Distribution of niobium, tantalum, and other highly incompatible trace elements in the lithospheric mantle: The spinel paradox. Geochim. Cosmochim. Acta 60, 545-550. doi:10.1016/0016-7037(95)00431-9

Brandon, A.D., Becker, H., Carlson, R.W., Shirey, S.B., 1999. Isotopic constraints on time scales and mechanisms of slab material transport in the mantle wedge: evidence from the Simcoe mantle xenoliths, Washington, USA. Chem. Geol. 160, 387-407. doi:10.1016/S0009-2541(99)00109-6

Chazot, G., Menzies, M., Harte, B., 1996. Silicate glasses in spinel Iherzolites from Yemen: origin and chemical composition. Chem. Geol. 134, 159-179. doi:10.1016/S00092541(96)00086-1

Coltorti, M., Beccaluva, L., Bonadiman, C., Faccini, B., Ntaflos, T., Siena, F., 2004. Amphibole genesis via metasomatic reaction with clinopyroxene in mantle xenoliths from Victoria Land, Antarctica. Lithos 75, 115-139. doi:10.1016/j.lithos.2003.12.021

Coltorti, M., Bonadiman, C., Faccini, B., Grégoire, M., O’Reilly, S.Y., Powell, W., 2007. Amphiboles from suprasubduction and intraplate lithospheric mantle. Lithos 99, 68-84. doi:10.1016/j.lithos.2007.05.009

Dantas, C., Grégoire, M., Koester, E., Conceição, R. V., Rieck, N., 2009. The Iherzolitewebsterite xenolith suite from Northern Patagonia (Argentina): Evidence of mantle-melt reaction processes. Lithos 107, 107-120. doi:10.1016/j.lithos.2008.06.012

Defant, M.J., Drummond, M.S., 1990. Derivation of some modern arc magmas by melting of young subducted lithosphere. Nature 347, 662-665.

Dick, H.J.B., Bullen, T., 1984. Chromian spinel as a petrogenetic indicator in abyssal and alpine-type peridotites and spatially associated lavas. Contrib. to Mineral. Petrol. 86, 54- 
76. doi:10.1007/BF00373711

Faccini, B., Bonadiman, C., Coltorti, M., Grégoire, M., Siena, F., 2013. Oceanic material recycled within the sub-patagonian lithospheric mantle (Cerro del Fraile, Argentina). J.

Petrol. 54, 1211-1258. doi:10.1093/petrology/egt010

Francis, D.M., 1976. Amphibole pyroxenite xenoliths: Cumulate or replacement phenomena from the upper mantle, Nunivak Island, Alaska. Contrib. to Mineral. Petrol. 58, 51-61. doi:10.1007/BF00384744

Gervasoni, F., Conceiçao, R.V., Jalowitzki, T.L.R., Schilling, M.E., Orihashi, Y., Nakai, S., Sylvester, P., 2012. Heterogeneidades do manto litosferico subcontinental no extremo sul da placa sul-americana: Influencia da subducçao atual e interaçoes litosferaastenosfera sob o campo vulcanico de Pali Aike. Pesqui. em Geociencias 39, 269-285.

Gervasoni, F., Klemme, S., Rohrbach, A., Grützner, T., Berndt, J., 2017. Experimental constraints on mantle metasomatism caused by silicate and carbonate melts. Lithos $282-$ 283, 173-186. doi:10.1016/j.lithos.2017.03.004

Gorring, M.L., Kay, S.M., 2000. Carbonatite metasomatized peridotite xenoliths from southern Patagonia: implications for lithospheric processes and Neogene plateau magmatism.

Contrib. to Mineral. Petrol. 140, 55-72. doi:10.1007/s004100000164

Grégoire, M., Jego, S., Maury, R.C., Polve, M., Payot, B., Tamayo, R.A., Yumul, G.P., 2008. Metasomatic interactions between slab-derived melts and depleted mantle: Insights from xenoliths within Monglo adakite (Luzon arc, Philippines). Lithos 103, 415-430. doi:10.1016/j.lithos.2007.10.013

Grégoire, M., McInnes, B.I.A., O’Reilly, S.Y., 2001. Hydrous metasomatism of oceanic subarc mantle, Lihir, Papua New Guinea: Part 2. Trace element characteristics of slabderived fluids. Lithos 59, 91-108. doi:10.1016/S0024-4937(01)00058-5 
Hawthorne, F.C., Oberti, R., Harlow, G.E., Maresch, W. V., Martin, R.F., Schumacher, J.C.,

Welch, M.D., 2012. IMA report: Nomenclature of the amphibole supergroup. Am. Mineral. 97, 2031-2048. doi:10.2138/am.2012.4276

Housh, T.B., Luhr, J.F., 1991. Plagioclase-melt equilibria in hydrous systems. Am. Mineral. $76,477-492$.

Ishimaru, S., Arai, S., Ishida, Y., Shirasaka, M., Okrugin, V.M., 2007. Melting and multi-stage metasomatism in the mantle wedge beneath a frontal arc inferred from highly depleted peridotite xenoliths from the avacha volcano, Southern Kamchatka. J. Petrol. 48, 395433. doi:10.1093/petrology/egl065

Johnston, A.D., Wyllie, P.J., 1989. The system tonalite-peridotite- $\mathrm{H}_{2} \mathrm{O}$ at $30 \mathrm{kbar}$, with applications to hybridization in subduction zone magmatism. Contrib. to Mineral. Petrol. 102, 257-264. doi:10.1007/BF00373719

Kay, S.M., Ramos, V.A., Marquez, M., 1993. Evidence in Cerro Pampa volcanic rocks for slab-melting prior to ridge-trench collisoion in Southern South America. J. Geol. 101, 701-714.

Kelemen, P.B., Hart, S.R., Bernstein, S., 1998. Silica enrichment in the continental upper mantle via melt/rock reaction. Earth Planet. Sci. Lett. 164, 387-406. doi:10.1016/S0012$821 \times(98) 00233-7$

Kepezhinskas, P.K., Defant, M.J., Drummond, M.S., 1995. Na metasomatism in the island-arc mantle by slab melt-peridotite interaction: Evidence from mantle xenoliths in the north Kamchatka arc. J. Petrol. 36, 1505-1527.

Kilian, R., Stern, C.R., 2002. Constraints on the interaction between slab melts and the mantle wedge from adakitic glass in peridotite xenoliths. Eur. J. Mineral. 14, 25-36. doi:10.1127/0935-1221/2002/0014-0025 
Kress, V., Carmichael, I., 1991. The compressibility of silicate liquids containing $\mathrm{Fe}_{2} \mathrm{O}_{3}$ and the effect of composition, temperature, oxygen fugacity and pressure on their redox states. Contrib. to Mineral. Petrol. 108, 82-92. doi:10.1007/bf00307328

Laurora, A., Mazzucchelli, M., Rivalenti, G., Vannucci, R., Zanetti, A., Barbieri, M. a,

Cingolani, C. a, 2001. Metasomatism and melting in carbonated peridotite xenoliths from the mantle wedge: The Gobernador Gregores case (southern Patagonia). J. Pet. 42, 6987. doi:10.1093/petrology/42.1.69

Le Bas, M.J., Streckeisen, A.L., 1991. The IUGS systematics of igneous rocks. J. Geol. Soc. London. 148, 825-833. doi:10.1144/gsjgs.148.5.0825

Lindsley, D.H., 1983. Pyroxene thermometry. Am. Mineral. 68, 477-493. doi:10.1007/BF00372872

Locock, A.J., 2014. An Excel spreadsheet to classify chemical analyses of amphiboles following the IMA 2012 recommendations. Comput. Geosci. 62, 1-11. doi:10.1016/j.cageo.2013.09.011

Mallik, A., Dasgupta, R., 2012. Reaction between MORB-eclogite derived melts and fertile peridotite and generation of ocean island basalts. Earth Planet. Sci. Lett. 329-330, 97108. doi:10.1016/j.epsl.2012.02.007

McDonough, W.F., Sun, S.-S., 1995. The composition of the Earth. Chem. Geol. 120, 223253- doi: 10.1016/0009-2541(94)00140-4

Mclnnes, B.I.A., Grégoire, M., Binns, R.A., Herzig, P.M., Hannington, M.D., 2001. Hydrous metasomatism of oceanic sub-arc mantle, Lihir, Papua New Guinea: Petrology and geochemistry of fluid-metasomatised mantle wedge xenoliths. Earth Planet. Sci. Lett. 188, 169-183. doi:10.1016/S0012-821X(01)00306-5

Mercier, J.C., Nicolas, A., 1975. Textures and fabrics of upper-mantle peridotites as illustrated 
by xenoliths from basalts. J. Petrol. 16, 454-487.

Morimoto, N., 1988. Nomenclature of Pyroxenes. Mineral. Petrol. 39, 55-76.

doi:10.1007/BF01226262

Neal, C.R., 1988. The origin and composition of metasomatic fluids and amphiboles beneath malaita, Solomon Islands. J. Petrol. 29, 149-179. doi:10.1093/petrology/29.1.149

Ntaflos, T., Bjerg, E.A., Labudia, C.H., Kurat, G., 2007. Depleted lithosphere from the mantle wedge beneath Tres Lagos, southern Patagonia, Argentina. Lithos 94, 46-65. doi:10.1016/j.lithos.2006.06.011

Pearson, D.G., Canil, D., Shirey, S.B., 2003. Mantle samples included in volcanic rocks: Xenoliths and diamonds, in: Treatise on Geochemistry. Volume 2. The Mantle and Core. Elsevier Ltd, pp. 171-275.

Prouteau, G., Scaillet, B., 2003. Experimental constraints on the origin of the 1991 Pinatubo dacite. J. Petrol. 44, 2203-2241. doi:10.1093/petrology/egg075

Prouteau, G., Scaillet, B., Pichavant, M., Maury, R., 2001. Evidence for mantle metasomatism by hydrous silicic melts derived from subducted oceanic crust. Nature 410, 197-200. doi:10.1038/35065583

Ramos, V.A., Kay, S.M., Singer, B.S., 2004. Las adakitas de la Cordillera Patagónica: Nuevas evidencias geoquímicas y geocronológicas. Rev. la Asoc. Geol. Argentina 59, 693-706.

Rapp, R.P., Shimizu, N., Norman, M.D., Applegate, G.S., 1999. Reaction between slabderived melts and peridotite in the mantle wedge: Experimental constraints at $3.8 \mathrm{GPa}$. Chem. Geol. 160, 335-356. doi:10.1016/S0009-2541(99)00106-0

Rivalenti, G., Mazzucchelli, M., Zanetti, A., Vannucci, R., Bollinger, C., Hémond, C., Bertotto, G.W., 2007. Xenoliths from Cerro de los Chenques (Patagonia): An example of slab- 
related metasomatism in the backarc lithospheric mantle. Lithos 99, 45-67. doi:10.1016/j.lithos.2007.05.012

Schiano, P., Clocchiatti, R., Shimizu, N., Maury, R., C., Jochum, K., P., Hofmann, A., W., 1995. Hydrous, silica-rich melts in the sub-arc mantle and their relationship with erupted arc lavas. Nature. doi:10.1038/377595a0

Schilling, M., Conceição, R. V., Mallmann, G., Koester, E., Kawashita, K., Hervé, F., Morata, D., Motoki, A., 2005. Spinel-facies mantle xenoliths from Cerro Redondo, Argentine Patagonia: Petrographic, geochemical, and isotopic evidence of interaction between xenoliths and host basalt. Lithos 82, 485-502. doi:10.1016/j.lithos.2004.09.028

Schneider, M.E., Eggler, D.H., 1986. Fluids in equilibrium with peridotite minerals: Implications for mantle metasomatism. Geochim. Cosmochim. Acta 50, 711-724. doi:10.1016/0016-7037(86)90347-9

Sekine, T., Wyllie, P.J., 1982a. The system granite-peridotite- $\mathrm{H}_{2} \mathrm{O}$ at $30 \mathrm{kbar}$, with applications to hybridization in subduction zone magmatism. Contrib. Mineral. Petrol. 81, 190-202. doi:10.1007/BF00371296

Sekine, T., Wyllie, P.J., 1982b. Synthetic systems for modeling hybridization between hydrous siliceous magmas and peridotite in subduction zones. J. Geol. 90, 734-741. doi:10.1086/628728

Sen, C., Dunn, T., 1994. Experimental modal metasomatism of a spinel Iherzolite and the production of amphibole-bearing peridotite. Contrib. to Mineral. Petrol. 119, 422-432. doi:10.1007/BF00286939

Shaw, C.S.J., 2009. Textural development of amphibole during breakdown reactions in a synthetic peridotite. Lithos 110, 215-228. doi:10.1016/j.lithos.2009.01.002

Shaw, C.S.J., Dingwell, D.B., 2008. Experimental peridotite-melt reaction at one atmosphere: 
A textural and chemical study. Contrib. to Mineral. Petrol. 155, 199-214.

doi:10.1007/s00410-007-0237-1

Shaw, C.S.J., Heidelbach, F., Dingwell, D.B., 2006. The origin of reaction textures in mantle peridotite xenoliths from Sal Island, Cape Verde: The case for "metasomatism" by the host lava. Contrib. to Mineral. Petrol. 151, 681-697. doi:10.1007/s00410-006-0087-2

Stern, C.R., Kilian, R., 1996. Role of the subducted slab, mantle wedge and continental crust in the generation of adakites from the Andean Austral Volcanic Zone. Contrib. to Mineral. Petrol. 123, 263-281. doi:10.1007/s004100050155

Suzuki, A.M., Yasuda, A., Ozawa, K., 2008. Cr and Al diffusion in chromite spinel:

Experimental determination and its implication for diffusion creep. Phys. Chem. Miner. 35, 433-445. doi:10.1007/s00269-008-0238-2

Syracuse, E.M., van Keken, P.E., Abers, G.A., Suetsugu, D., Bina, C., Inoue, T., Wiens, D., Jellinek, M., 2010. The global range of subduction zone thermal models. Phys. Earth Planet. Inter. 183, 73-90. doi:10.1016/j.pepi.2010.02.004

Wang, J., Hattori, K.H., Kilian, R., Stern, C.R., 2007. Metasomatism of sub-arc mantle peridotites below southernmost South America: Reduction of $\mathrm{fO}_{2}$ by slab-melt. Contrib. to Mineral. Petrol. 153, 607-624. doi:10.1007/s00410-006-0166-4

Wang, J., Hattori, K.H., Li, J., Stern, C.R., 2008a. Oxidation state of Paleozoic subcontinental lithospheric mantle below the Pali Aike volcanic field in southernmost Patagonia. Lithos 105, 98-110. doi:10.1016/j.lithos.2008.02.009

Wang, J., Hattori, K.H., Stern, C.R., 2008b. Metasomatic origin of garnet orthopyroxenites in the subcontinental lithospheric mantle underlying Pali Aike volcanic field, southern South America. Mineral. Petrol. 94, 243-258. doi:10.1007/s00710-008-0017-2

Yaxley, G.M., Kamenetsky, V., 1999. In situ origin for glass in mantle xenoliths from 
southeastern Australia: Insights from trace element compositions of glasses and metasomatic phases. Earth Planet. Sci. Lett. 172, 97-109. doi:10.1016/S0012821X(99)00196-X

Zanetti, A., Mazzucchelli, M., Rivalenti, G., Vannucci, R., 1999. The Finero phlogopiteperidotite massif: an example of subduction-related metasomatism. Contrib. to Mineral. Petrol. 134, 107-122. doi:10.1007/s004100050472 


\section{Figure captions}

Figure 1. Back-scattered electron images and color-coded compositional maps of some of the experimental run products. (a) Formation of metasomatic orthopyroxene (Opx-M) at the expense of primary olivine (OI-P) present at the peridotite-adakite interface of run \#124 (1.5 $\left.\mathrm{GPa}, 1100^{\circ} \mathrm{C}\right)$. Crystallization of secondary clinopyroxene $(\mathrm{Cpx}-\mathrm{X})$ also takes place near the interface. It is related to the crystallization of the adakitic melt rather than a metasomatic reaction stricto senso (see discussion in text). (b) Incongruent dissolution of primary spinel (Sp-P) and formation of secondary metasomatic spinel (Sp-M) along the initial peridotiteadakite interface and along grain boundaries infiltrated by melt (run \#128). (c) Formation of pargasitic amphibole (Amp-M) under water-rich conditions along primary clinopyroxene (CpxP)-olivine (OI-P) grain boundaries (run \#132). Fibrous metasomatic orthopyroxene (Opx-M) also formed following incongruent dissolution of primary olivine. (d) Crystallization of clinopyroxene $(\mathrm{Cpx}-\mathrm{X})$ at the initial peridotite-adakite interface of run \#132. Preservation of the interface precludes the participation of primary clinopyroxene $(\mathrm{Cpx}-\mathrm{P})$ in the formingreaction of secondary clinopyroxene (see discussion in text). (e) Crystallization of plagioclase (Plag-X), clinopyroxene $(\mathrm{Cpx}-\mathrm{X})$ and orthopyroxene $(\mathrm{Opx}-\mathrm{X})$ along the interface and within the adakitic portion of the experimental charge (run \#125). Also noticeable is the formation of metasomatic spinel (Sp-M) as a thin reaction rim of primary spinel (Sp-P). (f) Preservation of the primary orthopyroxene-adakite melt interface characterized by the absence of reaction rim or dissolution (run \#132). Also noticeable is the formation of metasomatic orthopyroxene $(\mathrm{Opx}-\mathrm{M})$ as a reaction rim of primary olivine $(\mathrm{OI}-\mathrm{P})$ and the crystallization of secondary clinopyroxene (Cpx-X). 
Figure 2. Part of the ternary En-Fs-Wo plot (Morimoto, 1988) showing the chemical variations of metasomatic orthopyroxene (Opx-M) produced from primary olivine-melt reaction. The composition of primary orthopyroxene (Opx-P) is also shown for comparison.

Figure 3. Chemical gradient observed in metasomatic spinel (Sp-M) compared to the compositional range observed in primary spinel core and rim (Sp-P).

Figure 4. Primitive Mantle-normalized REE and multi-element patterns of primary and secondary clinopyroxene (Cpx-P, CPx-X) and adakitic melt of run \#132. The composition of the Cerro Pampa adakite is also shown for comparison. Primitive mantle values are taken from McDonough and Sun (1995)

Figure 5. Calcic amphibole classification diagram following new IMA recommendations (Hawthorne et al., 2012) comparing the range of natural amphiboles from suprasubduction settings (Coltorti et al., 2007) and experimental amphiboles produced from the interaction between peridotite and slab-derived melts. Calculations were made using the excel spreadsheet of Locock (2014). Note that pargasite is defined as having $\mathrm{Al}_{\mathrm{VI}}>\mathrm{Fe}^{3+}$ in the $\mathrm{C}$ site, while Mg-hastingsite has $\mathrm{Al}_{\mathrm{V} I}<\mathrm{Fe}^{3+}$.

Figure 6. Molar $\mathrm{MgO}-\mathrm{CaO}-\mathrm{FeO}^{t}$ ternary diagram showing the composition of experimentally produced amphiboles in comparison with the compositional range of natural amphiboles from mantle wedge xenoliths (Coltorti et al., 2007). 
Table 1. Whole-rock element composition of starting materials.

\begin{tabular}{|c|c|c|c|}
\hline & $\begin{array}{l}\text { Lherzolite } \\
(\text { (PM18-2) }\end{array}$ & Adakite $^{2}$ & Adakite $^{3}$ \\
\hline$\overline{\mathrm{SiO}_{2} \text { (wt\%) }}$ & 44.5 & 62.5 & 62.1 \\
\hline $\mathrm{TiO}_{2}$ & 0.05 & 0.63 & 0.61 \\
\hline $\mathrm{Al}_{2} \mathrm{O}_{3}$ & 2.15 & 17.6 & 16.9 \\
\hline $\mathrm{Cr}_{2} \mathrm{O}_{3}$ & 0.35 & 0.01 & 0.01 \\
\hline $\mathrm{FeO}$ & 7.32 & 3.14 & 3.17 \\
\hline $\mathrm{MnO}$ & 0.13 & 0.05 & 0.06 \\
\hline $\mathrm{MgO}$ & 44.1 & 3.71 & 3.73 \\
\hline $\mathrm{CaO}$ & 1.35 & 6.30 & 6.33 \\
\hline $\mathrm{Na}_{2} \mathrm{O}$ & 0.27 & 4.96 & 4.74 \\
\hline $\mathrm{K}_{2} \mathrm{O}$ & 0.02 & 1.22 & 1.28 \\
\hline $\mathrm{P}_{2} \mathrm{O}_{5}$ & 0.03 & 0.20 & 0.18 \\
\hline $\mathrm{NiO}$ & 0.30 & - & 0.01 \\
\hline Total & 100.6 & 100.3 & 99.1 \\
\hline Mg\# & 0.915 & 0.68 & 0.68 \\
\hline Sc (ppm) & 7.2 & 7 & n.m. \\
\hline V & 47 & 60 & n.m. \\
\hline $\mathrm{Cr}$ & 2400 & 90 & 85 \\
\hline Co & 115 & 12 & 14.6 \\
\hline $\mathrm{Ni}$ & 2319 & 76 & 72 \\
\hline $\mathrm{Cu}$ & 3 & 23 & n.m. \\
\hline $\mathrm{Zn}$ & 51 & 44 & n.m. \\
\hline $\mathrm{Rb}$ & 0.36 & 19.3 & 21.6 \\
\hline $\mathrm{Sr}$ & 20.17 & 2110 & 1920 \\
\hline Y & - & 7.9 & 7.2 \\
\hline $\mathrm{Zr}$ & 7.56 & 131 & 110 \\
\hline $\mathrm{Nb}$ & 1.53 & 9.8 & 9.0 \\
\hline Mo & 0.34 & $<1$ & n.m. \\
\hline Sn & 0.45 & $<1$ & n.m. \\
\hline Cs & 0.02 & 0.25 & 0.22 \\
\hline $\mathrm{Ba}$ & 8.22 & 296 & 288 \\
\hline La & 1.58 & 26.4 & 27.7 \\
\hline $\mathrm{Ce}$ & 3.15 & 57 & 63 \\
\hline $\operatorname{Pr}$ & 0.41 & 6.8 & 6.9 \\
\hline $\mathrm{Nd}$ & 1.71 & 25.5 & 25.8 \\
\hline $\mathrm{Sm}$ & 0.36 & 4.1 & 3.8 \\
\hline Eu & 0.11 & 1.2 & 1.1 \\
\hline $\mathrm{Gd}$ & 0.43 & 2.7 & 2.4 \\
\hline $\mathrm{Tb}$ & 0.05 & 0.35 & 0.28 \\
\hline Dy & 0.26 & 1.7 & 1.6 \\
\hline Ho & 0.05 & 0.29 & 0.26 \\
\hline $\mathrm{Er}$ & 0.15 & 0.88 & 0.70 \\
\hline $\mathrm{Tm}$ & 0.02 & 0.13 & 0.09 \\
\hline $\mathrm{Yb}$ & 0.14 & 0.66 & 0.64 \\
\hline Lu & 0.02 & 0.10 & 0.09 \\
\hline $\mathrm{Hf}$ & 0.19 & 3.4 & 2.7 \\
\hline $\mathrm{Ta}$ & 0.11 & 0.70 & 0.62 \\
\hline $\mathrm{Pb}$ & 0.9 & $<2$ & 5.2 \\
\hline Th & 0.21 & 4.9 & 4.7 \\
\hline$\underline{U}$ & 0.05 & 1.2 & 1.4 \\
\hline
\end{tabular}

Abbreviation used: n.m., not measured.

${ }^{1}$ From Gervasoni et al. (2012).

${ }^{2}$ This study, ALS Chemex data from powdered sample.

${ }^{3}$ This study, EPMA and LA-ICP-MS analyzes on glass bead. 
Table 2. Experimental conditions (all runs at $1.5 \mathrm{GPa}$ ).

\begin{tabular}{|c|c|c|c|c|}
\hline Run & $\mathrm{T}\left({ }^{\circ} \mathrm{C}\right)$ & $\mathrm{t}(\mathrm{h})$ & Water $^{1}$ & Main textural observations at the melt-rock interface ${ }^{2}$ \\
\hline$\# 120$ & 1250 & 89 & Anhydrous & $\begin{array}{l}\text { Cpx-P and Opx-P at the interface not affected by metasomatism. } \\
\text { No Sp-P exposed at the interface. } \\
\text { Precipitation of a } 10 \mu \mathrm{m} \text { thick layer of Opx-M at the expense of OI-P. } \\
\text { Precipitation of Cpx-X up to } 50 \mu \mathrm{m} \text { and Plag-X up to } 80 \mu \mathrm{m} \text { at the interface and within adakitic } \\
\text { melt portion. }\end{array}$ \\
\hline \#123 & 1300 & 48 & Anhydrous & $\begin{array}{l}\text { Cpx-P at the interface not affected by metasomatism. } \\
\text { No Sp-P and Opx-P exposed at the interface. } \\
\text { Precipitation of a } 10 \mu \mathrm{m} \text { thick layer of Opx-M at the expense of OI-P. } \\
\text { No precipitation of Cpx-X or Plag-X within adakitic melt portion. }\end{array}$ \\
\hline \#124 & 1100 & 90 & $\sim 6 \mathrm{wt} \%$ & $\begin{array}{l}\text { Cpx-P and Opx-P at the interface not affected by metasomatism. } \\
\text { Precipitation of a } 10 \mu \mathrm{m} \text { thick layer of Opx-M at the expense of OI-P. } \\
\text { Formation of a } 10-20 \mu \mathrm{m} \text { thick layer of sieved Sp-M at the expense of Sp-P. } \\
\text { Precipitation of Cpx-X up to } 40 \mu \mathrm{m} \text { within adakitic melt portion. }\end{array}$ \\
\hline$\# 125$ & 1000 & 40 & $\sim 9 w t \%$ & $\begin{array}{l}\text { No Cpx-P and Opx-P exposed at the interface. } \\
\text { Sp-P observed at the interface with a } 2 \mu \mathrm{m} \text { sieved Sp-M reaction rim. } \\
\text { Precipitation of a } 5 \mu \mathrm{m} \text { thick layer of Opx-M at the expense of Ol-P. } \\
\text { Precipitation of Cpx-X, Plag-X and Opx-X up to } 50 \mu \mathrm{m} \text { within adakitic melt portion. } \\
\text { Precipitation of Cpx-M and Amp-M up to } 10 \mu \mathrm{m} \text { between Sp-P and OI-P. }\end{array}$ \\
\hline \#128 & 1000 & 72 & $\sim 5 \mathrm{wt} \%$ & $\begin{array}{l}\text { Cpx-P at the interface not affected by metasomatism. } \\
\text { Precipitation of a } 10-20 \mu \mathrm{m} \text { thick layer of Opx-M at the expense of OI-P. } \\
\text { Formation of a } 50-70 \mu \mathrm{m} \text { thick layer of sieved Sp-M at the expense of Sp-P. } \\
\text { Precipitation of Cpx-X up to } 40 \mu \mathrm{m} \text { within adakitic melt portion. }\end{array}$ \\
\hline$\# 132$ & 1050 & 116 & $\sim 12 \mathrm{wt} \%$ & $\begin{array}{l}\text { Cpx-P and Opx-P at the interface not affected by metasomatism. } \\
\text { No Sp-P exposed at the interface. } \\
\text { Precipitation of Cpx-X up to } 100 \mu \mathrm{m} \text { at/near the interface. } \\
\text { Precipitation of Amp-M up to } 80 \mu \mathrm{m} \text { in infiltrated melt. } \\
\text { Precipitation of a } 20-\mu \mathrm{m} \text { thick layer of Opx-M at the expense of OI-P. }\end{array}$ \\
\hline
\end{tabular}


Table 3. Representative compositions of experimental silicate phases present near the peridotite-adakitic melt interface.

\begin{tabular}{|c|c|c|c|c|c|c|c|c|c|c|c|}
\hline \multirow[b]{2}{*}{ (wt\%) } & \multicolumn{7}{|l|}{$\# 120$} & \multicolumn{4}{|l|}{ \#123 } \\
\hline & Liq & Ol-P & Opx-P & Cpx-P & Opx-M & Сpx-X & Plag-X & Liq & OI-P & Cpx-P & Opx-M \\
\hline $\mathrm{SiO}_{2}$ & 64.6 & 41.1 & 55.9 & 53.3 & 56.0 & 54.8 & 60.2 & 62.3 & 41.8 & 53.0 & 59.1 \\
\hline $\mathrm{TiO}_{2}$ & 1.03 & n.d. & n.d. & 0.18 & 0.19 & 0.30 & n.d. & 0.69 & n.d. & 0.19 & 0.15 \\
\hline $\mathrm{Al}_{2} \mathrm{O}_{3}$ & 16.4 & 0.10 & 3.89 & 4.97 & 3.77 & 4.37 & 25.0 & 17.6 & 0.09 & 5.04 & 3.64 \\
\hline $\mathrm{Cr}_{2} \mathrm{O}_{3}$ & n.d. & n.d. & 0.37 & 0.82 & 0.09 & 0.13 & n.d. & n.d. & n.d. & 0.92 & 0.12 \\
\hline $\mathrm{FeO}^{\mathrm{t}}$ & 1.06 & 9.14 & 5.89 & 2.79 & 4.83 & 2.50 & 0.11 & 0.29 & 9.17 & 2.66 & 0.75 \\
\hline $\mathrm{MnO}$ & n.d. & 0.15 & 0.14 & 0.12 & 0.16 & 0.16 & 0.02 & n.d. & 0.14 & 0.08 & 0.09 \\
\hline $\mathrm{MgO}$ & 3.35 & 49.3 & 33.7 & 16.5 & 33.2 & 21.0 & 0.21 & 5.98 & 48.4 & 15.9 & 35.6 \\
\hline $\mathrm{CaO}$ & 5.07 & 0.12 & 0.62 & 21.0 & 1.43 & 16.4 & 7.29 & 7.01 & n.d. & 21.1 & 1.51 \\
\hline $\mathrm{Na}_{2} \mathrm{O}$ & 4.30 & n.d. & 0.07 & 1.22 & 0.10 & 0.81 & 6.80 & 4.03 & n.d. & 1.23 & 0.13 \\
\hline $\mathrm{K}_{2} \mathrm{O}$ & 1.69 & n.d. & n.d. & n.d. & n.d. & n.d. & 0.47 & 1.13 & n.d. & n.d. & n.d. \\
\hline $\mathrm{NiO}$ & n.d. & 0.38 & 0.11 & n.d. & 0.09 & n.d. & n.d. & n.d. & 0.40 & n.d. & n.d. \\
\hline $\mathrm{P}_{2} \mathrm{O}_{5}$ & 0.28 & n.d. & n.d. & n.m. & n.d. & n.d. & n.d. & I & n.m. & n.m. & n.m. \\
\hline Total & 97.8 & 100.3 & 100.7 & 100.9 & 99.9 & 100.5 & 100.1 & 9.0 & 100.0 & 100.1 & 101.1 \\
\hline Mg\# & 0.88 & 0.90 & 0.91 & 0.91 & 0.92 & 0.94 & & & 0.90 & 0.91 & 0.99 \\
\hline$\%$ En & & & 90.0 & 49.8 & 89.9 & 61.3 & & & & 48.8 & 95.9 \\
\hline$\% F s$ & & & 8.8 & 4.7 & 7.3 & 4.1 & & & & 4.6 & 1.1 \\
\hline$\%$ Wo & & & 1.2 & 45.5 & 2.8 & 34.6 & & & & 46.6 & 3.0 \\
\hline$\% A n$ & & & & & & & & & & & \\
\hline $\mathrm{Fe} / \mathrm{Mg}$ & 0.14 & 0.10 & 0.10 & 0.10 & 0.08 & 0.07 & & 0.02 & 0.11 & 0.10 & 0.01 \\
\hline
\end{tabular}

\begin{tabular}{|c|c|c|c|c|c|c|c|c|c|c|c|c|c|c|}
\hline \multirow[b]{2}{*}{ (wt\%) } & \multicolumn{6}{|l|}{$\# 124$} & \multicolumn{8}{|c|}{$\# 125$} \\
\hline & Liq & Ol-P & Opx-P & Cpx-P & Opx-N & Cpx-X & Liq & Ol-P & Cpx-P & Opx-N & Amp-M & Opx-X & Cpx-X & Plag-X \\
\hline $\mathrm{SiO}_{2}$ & 61.5 & 41.6 & 55.6 & 53.2 & 56.4 & 53.3 & 60.2 & 40.2 & 53.6 & 53.8 & 44.1 & 53.4 & 50.2 & 54.8 \\
\hline $\mathrm{TiO}_{2}$ & 0.67 & n.d. & 0.05 & 0.24 & 0.17 & 0.46 & 0.57 & n.d. & 0.16 & 0.28 & 1.50 & 0.19 & 0.86 & n.d. \\
\hline $\mathrm{Al}_{2} \mathrm{O}_{3}$ & 19.4 & n.d. & 3.76 & 5.19 & 3.32 & 5.34 & 17.9 & n.d. & 4.82 & 3.97 & 13.9 & 3.73 & 5.31 & 27.0 \\
\hline $\mathrm{Cr}_{2} \mathrm{O}_{3}$ & n.d. & n.d. & 0.36 & 0.80 & n.d. & 0.24 & n.d. & n.d. & 0.90 & n.d. & 1.55 & n.d. & n.d. & n.d. \\
\hline $\mathrm{FeO}^{\mathrm{t}}$ & 0.46 & 9.09 & 5.96 & 2.81 & 3.01 & 2.25 & 1.91 & 9.31 & 2.72 & 8.43 & 4.97 & 11.2 & 6.04 & 0.62 \\
\hline $\mathrm{MnO}$ & n.d. & 0.14 & 0.15 & 0.09 & 0.15 & 0.12 & n.d. & 0.15 & 0.10 & 0.19 & 0.10 & 0.28 & 0.14 & n.d. \\
\hline $\mathrm{MgO}$ & 2.59 & 49.6 & 34.1 & 15.9 & 37.3 & 17.1 & 1.65 & 49.7 & 16.1 & 31.8 & 17.0 & 29.5 & 14.9 & 0.22 \\
\hline $\mathrm{CaO}$ & 4.55 & n.d. & 0.65 & 20.8 & 0.77 & 20.9 & 3.46 & n.d. & 21.1 & 0.70 & 11.0 & 0.99 & 20.3 & 9.87 \\
\hline $\mathrm{Na}_{2} \mathrm{O}$ & 2.81 & n.d. & 0.07 & 1.42 & n.d. & 0.88 & 3.53 & n.d. & 1.32 & 0.07 & 2.76 & 0.08 & 0.89 & 5.72 \\
\hline $\mathrm{K}_{2} \mathrm{O}$ & 1.36 & n.d. & n.d. & n.d. & n.d. & n.d. & 1.59 & n.d. & n.d. & n.d. & 0.40 & n.d. & n.d. & 0.25 \\
\hline $\mathrm{NiO}$ & n.d. & 0.40 & 0.12 & n.d. & 0.17 & n.d. & 0.01 & 0.36 & n.d. & 0.16 & 0.10 & n.d. & n.d. & n.d. \\
\hline $\mathrm{P}_{2} \mathrm{O}_{5}$ & n.m. & n.m. & n.m. & n.m. & n.m. & n.m. & 0.27 & n.d. & n.m. & n.d. & 0.10 & n.d. & n.d. & n.d. \\
\hline Total & 93.3 & 100.8 & 100.8 & 100.5 & 101.3 & 100.6 & 91.1 & 99.7 & 100.9 & 99.4 & 98.7 & 99.4 & 98.8 & 98.5 \\
\hline Mg\# & 0.93 & 0.90 & 0.91 & 0.91 & 0.96 & 0.94 & 0.66 & 0.90 & 0.91 & 0.87 & 0.86 & 0.82 & 0.81 & \\
\hline$\%$ En & & & 90.0 & 49.0 & 94.5 & 51.2 & & & 49.2 & 85.9 & & 80.9 & 45.2 & \\
\hline$\% F s$ & & & 8.8 & 4.9 & 3.9 & 3.8 & & & 4.7 & 12.8 & & 17.2 & 10.3 & \\
\hline$\%$ Wo & & & 1.2 & 46.1 & 1.6 & 45.0 & & & 46.1 & 1.4 & & 1.9 & 44.5 & \\
\hline$\% A n$ & & & & & & & & & & & & & & 48.1 \\
\hline $\mathrm{Fe} / \mathrm{Mg}$ & 0.08 & 0.10 & 0.10 & 0.10 & 0.04 & 0.07 & 0.52 & 0.09 & 0.09 & 0.15 & 0.16 & 0.21 & 0.23 & \\
\hline
\end{tabular}




\begin{tabular}{|c|c|c|c|c|c|c|c|c|c|c|c|c|}
\hline \multirow[b]{2}{*}{ (wt\%) } & \multicolumn{5}{|l|}{ \#128 } & \multicolumn{7}{|l|}{$\# 132$} \\
\hline & Liq & Ol-P & Cpx-P & Opx-M & Сpx-X & Liq & Ol-P & Opx-P & Cpx-P & Opx-M & Amp-M & Cpx-X \\
\hline $\mathrm{SiO}_{2}$ & 56.7 & 41.5 & 53.3 & 58.6 & 54.2 & 56.4 & 40.9 & 55.7 & 52.5 & 55.8 & 44.1 & 52.3 \\
\hline $\mathrm{TiO}_{2}$ & 0.58 & n.d. & 0.17 & 0.12 & 0.25 & 0.58 & n.d. & n.d. & 0.17 & 0.14 & 1.15 & 0.39 \\
\hline $\mathrm{Al}_{2} \mathrm{O}_{3}$ & 17.7 & n.d. & 5.03 & 3.68 & 4.00 & 17.2 & n.d. & 3.99 & 5.07 & 3.38 & 13.4 & 4.31 \\
\hline $\mathrm{Cr}_{2} \mathrm{O}_{3}$ & n.d. & n.d. & 0.84 & 0.07 & 0.40 & n.d. & n.d. & 0.41 & 0.91 & n.d. & 0.84 & 0.07 \\
\hline $\mathrm{FeO}^{\mathrm{t}}$ & 2.44 & 9.15 & 2.74 & 3.78 & 2.89 & 2.06 & 9.21 & 5.86 & 2.73 & 6.23 & 4.90 & 4.49 \\
\hline $\mathrm{MnO}$ & n.d. & 0.13 & 0.09 & 0.11 & 0.11 & n.d. & 0.13 & 0.16 & 0.09 & 0.16 & n.d. & 0.14 \\
\hline $\mathrm{MgO}$ & 5.13 & 49.2 & 16.0 & 32.2 & 18.0 & 2.68 & 49.3 & 33.0 & 15.9 & 33.5 & 17.9 & 16.0 \\
\hline $\mathrm{CaO}$ & 6.76 & n.d. & 20.9 & 1.65 & 20.0 & 4.45 & n.d. & 0.66 & 21.0 & 0.75 & 11.0 & 21.1 \\
\hline $\mathrm{Na}_{2} \mathrm{O}$ & 4.70 & n.d. & 1.38 & 0.29 & 0.85 & 3.67 & n.d. & 0.09 & 1.45 & 0.06 & 2.95 & 0.92 \\
\hline $\mathrm{K}_{2} \mathrm{O}$ & 1.15 & n.d. & n.d. & 0.12 & n.d. & 1.41 & n.d. & n.d. & n.d. & n.d. & 0.47 & n.d. \\
\hline $\mathrm{NiO}$ & n.m. & n.m. & 0.08 & 0.10 & n.d. & n.d. & 0.38 & 0.08 & n.d. & 0.15 & 0.11 & n.d. \\
\hline $\mathrm{P}_{2} \mathrm{O}_{5}$ & n.m. & n.m. & n.m. & n.m. & n.m. & 0.26 & n.d. & n.d. & n.d. & n.d. & n.d. & n.d. \\
\hline Total & 95.2 & 100.0 & 100.5 & 100.7 & 100.7 & 88.7 & 99.9 & 100.0 & 99.8 & 100.2 & 96.9 & 99.7 \\
\hline Mg\# & 0.82 & 0.90 & 0.91 & 0.94 & 0.92 & 0.74 & 0.90 & 0.91 & 0.91 & 0.91 & 0.87 & 0.86 \\
\hline$\%$ En & & & 49.1 & 90.6 & 52.9 & & & 89.8 & 48.9 & 89.3 & & 47.5 \\
\hline$\% F s$ & & & 4.7 & 6.0 & 4.8 & & & 8.9 & 4.7 & 9.3 & & 7.5 \\
\hline$\%$ Wo & & & 46.1 & 3.4 & 42.4 & & & 13 & 46.4 & 1.4 & & 45.0 \\
\hline$\% A n$ & & & & & & & & & & & & \\
\hline $\mathrm{Fe}^{2+} / \mathrm{Mg}$ & 0.21 & 0.10 & 0.10 & 0.07 & 0.09 & 0.34 & 0.11 & 0.10 & 0.10 & 0.10 & 0.15 & 0.16 \\
\hline
\end{tabular}

Abbreviations: Cpx, clinopyroxene; Opx, orthopyroxene; Ol, olivine; Sp, spinel; Amp, pargasitic amphibole; Plag, plagioclase. Suffixes: $P$, primary mineral; $M$, secondary metasomatic mineral; $X$, secondary mineral solely produced from the crystallization of the adakitic melt. Mg\#, Mg-number defined as molar ratio $\mathrm{Mg} /\left(\mathrm{Mg}+\mathrm{Fe}^{2+}\right)$ $\mathrm{Fe}^{2+} / \mathrm{Mg}$ and $\mathrm{Mg} \#$ in Liq was calculated considering $80 \% \mathrm{Fe}$ as $\mathrm{Fe}^{2+}$, as estimated from Kress and Carmichael (1991) for the experimental conditions of this study.

$\mathrm{Fe}^{2+} / \mathrm{Mg}$ in olivine and pyroxene determined from stoichiometry. 
Table 4. Representative compositions of experimental spinels present near the peridotiteadakitic melt interface.

\begin{tabular}{|c|c|c|c|c|c|}
\hline \multirow[b]{2}{*}{ (wt\%) } & \multicolumn{2}{|l|}{$\# 124$} & \multirow{2}{*}{$\frac{\# 125}{\text { Sp-P }}$} & \multicolumn{2}{|l|}{ \#128 } \\
\hline & Sp-P & Sp-M & & Sp-P & Sp-M \\
\hline $\mathrm{SiO}_{2}$ & 0.06 & 0.31 & 0.08 & 0.09 & 0.37 \\
\hline $\mathrm{TiO}_{2}$ & 0.25 & 0.22 & 0.27 & 0.20 & 0.20 \\
\hline $\mathrm{Al}_{2} \mathrm{O}_{3}$ & 48.8 & 40.1 & 48.4 & 49.8 & 38.4 \\
\hline $\mathrm{Cr}_{2} \mathrm{O}_{3}$ & 18.7 & 31.2 & 18.6 & 17.5 & 29.5 \\
\hline $\mathrm{Fe}_{2} \mathrm{O}_{3}{ }^{1}$ & 2.97 & 0.00 & 2.93 & 2.69 & 2.85 \\
\hline $\mathrm{FeO}^{1}$ & 10.2 & 7.67 & 10.1 & 9.86 & 8.26 \\
\hline $\mathrm{MnO}$ & 0.09 & 0.09 & 0.10 & 0.11 & 0.09 \\
\hline $\mathrm{MgO}$ & 19.6 & 19.7 & 19.5 & 19.7 & 19.7 \\
\hline $\mathrm{NiO}$ & 0.34 & 0.22 & 0.31 & 0.36 & 0.30 \\
\hline Total & 101.0 & 99.4 & 100.0 & 100.3 & 99.7 \\
\hline Mg\# & 0.77 & 0.82 & 0.77 & 0.78 & 0.81 \\
\hline Cr\# & 0.20 & 0.34 & 0.21 & 0.19 & 0.34 \\
\hline$\% A l$ & 77.1 & 65.7 & 77.1 & 78.6 & 63.9 \\
\hline$\% \mathrm{Fe}^{3+}$ & 3.0 & 0.0 & 3.0 & 2.7 & 3.0 \\
\hline$\% \mathrm{Cr}$ & 19.9 & 34.3 & 19.9 & 18.7 & 33.0 \\
\hline
\end{tabular}

Determined from $\mathrm{FeO}^{\text {total }}$ assuming spinel stoichiometry.

Abbreviations: $\mathrm{Sp}-\mathrm{P}$, primary spinel; $\mathrm{Sp}-\mathrm{M}$, metasomatic secondary spinel observed as a rim of primary spinel; $\mathrm{Mg \# ,} \mathrm{Mg-number} \mathrm{defined} \mathrm{as} \mathrm{molar} \mathrm{ratio} \mathrm{Mg} /\left(\mathrm{Mg}+\mathrm{Fe}^{2+}\right)$; $\mathrm{Cr}$, $\mathrm{Cr}$-number defined as molar ratio $\mathrm{Cr} /(\mathrm{Cr}+\mathrm{Al}), \% \mathrm{Al}$, $\% \mathrm{Fe}^{3+}, \% \mathrm{Cr}$ indicate percentage of $\mathrm{Al}, \mathrm{Fe}^{3+}$ and $\mathrm{Cr}$ components in $\left(\mathrm{Mg}, \mathrm{Fe}^{2+}\right)\left(\mathrm{Al}, \mathrm{Cr}, \mathrm{Fe}^{3+}\right)_{2} \mathrm{O}_{4}$ spinel. 


\section{Highlights}

- We performed experiments to simulate mantle wedge metasomatism by adakitic melts

- Adakitic metasomatism leads to the dissolution of primary olivine and spinel

- Fibrous secondary orthopyroxene is formed at the expense of primary olivine

- High-Cr secondary spinel is formed at the expense of primary spinel

- Pargasite forms at clinopyroxene grain boundaries under highly hydrous conditions 

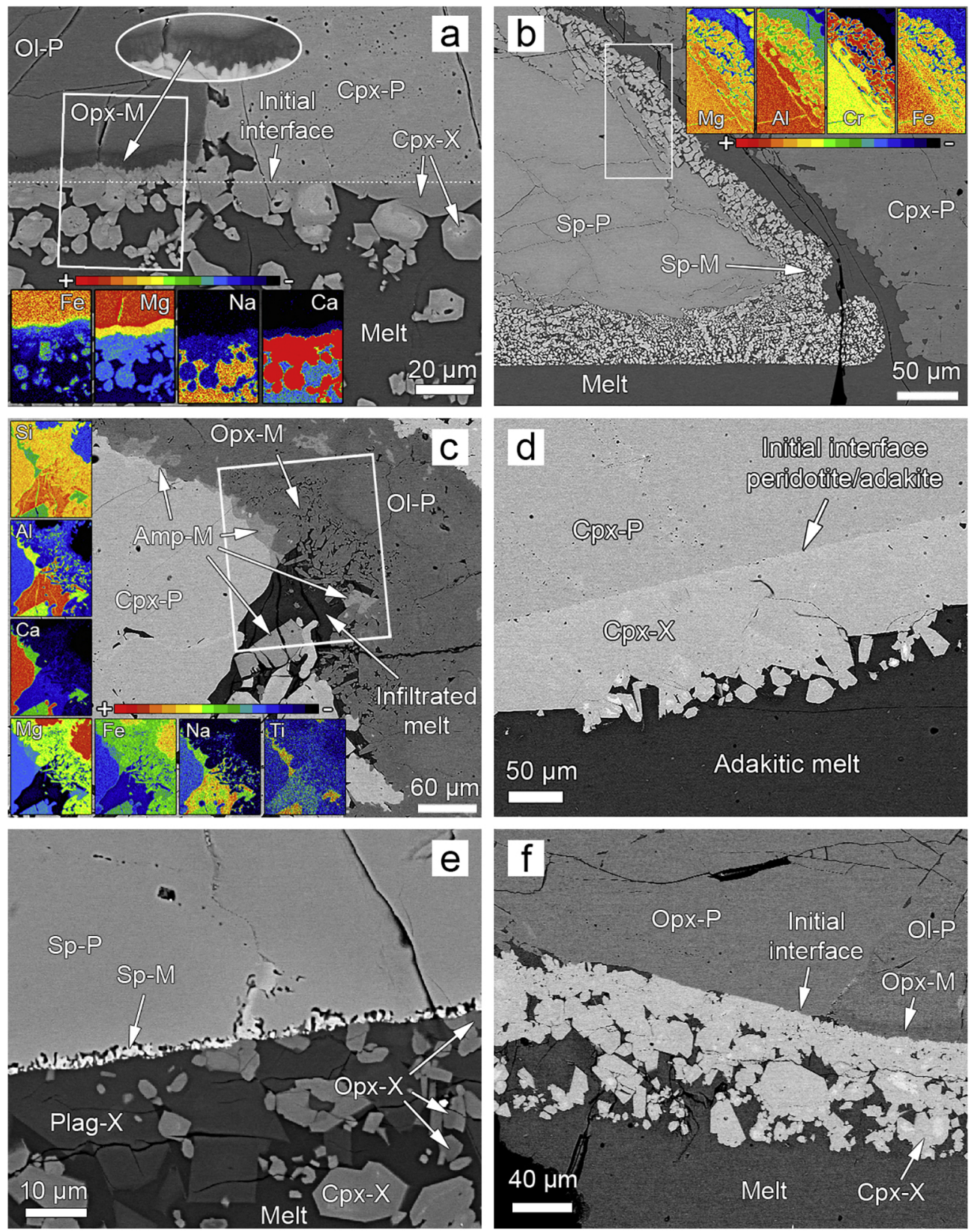

Figure 1 
$\mathrm{Wo}_{10}$

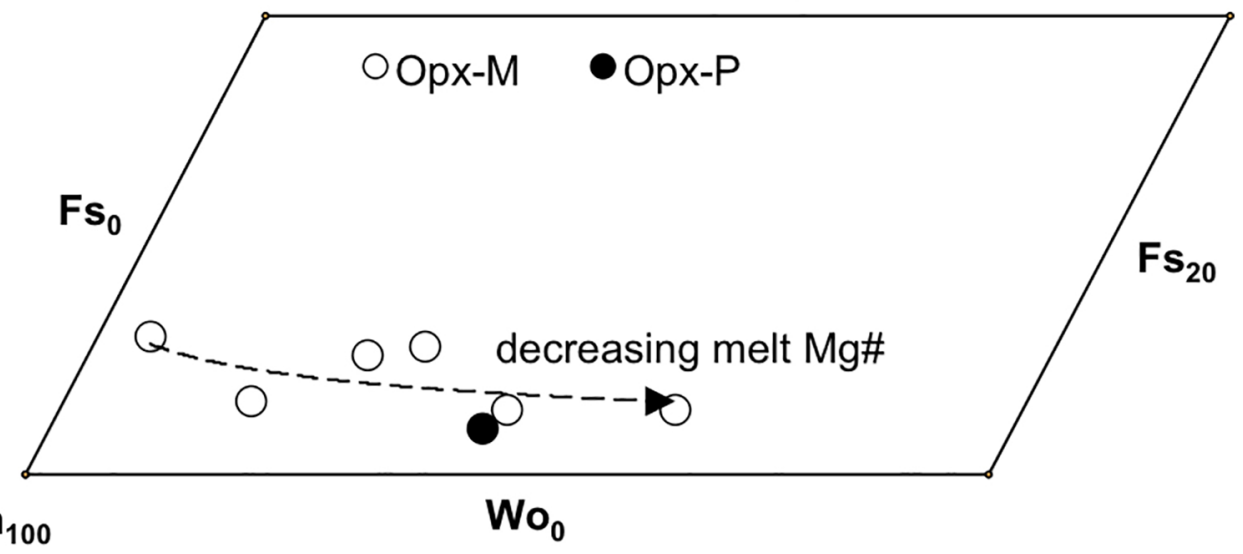

Figure 2 


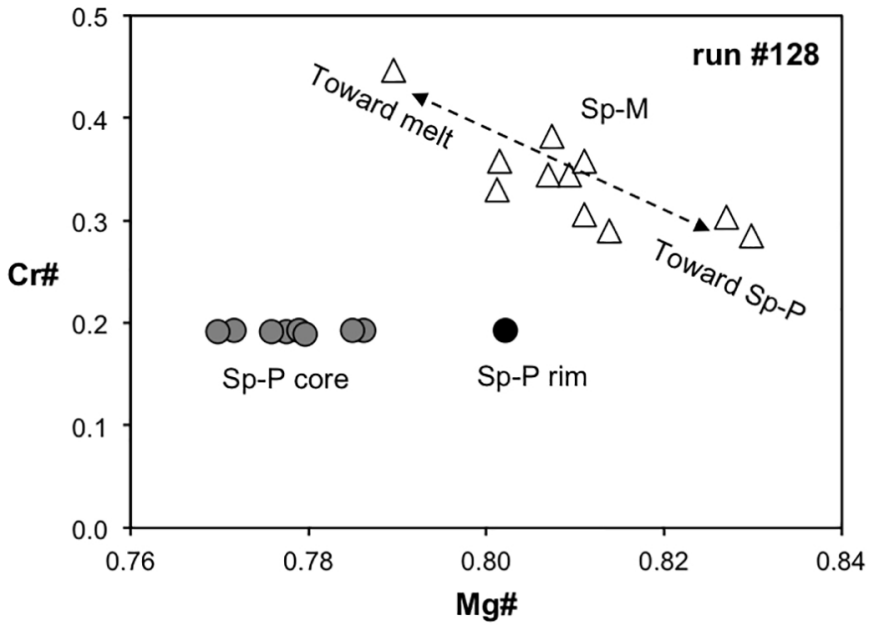

Figure 3 

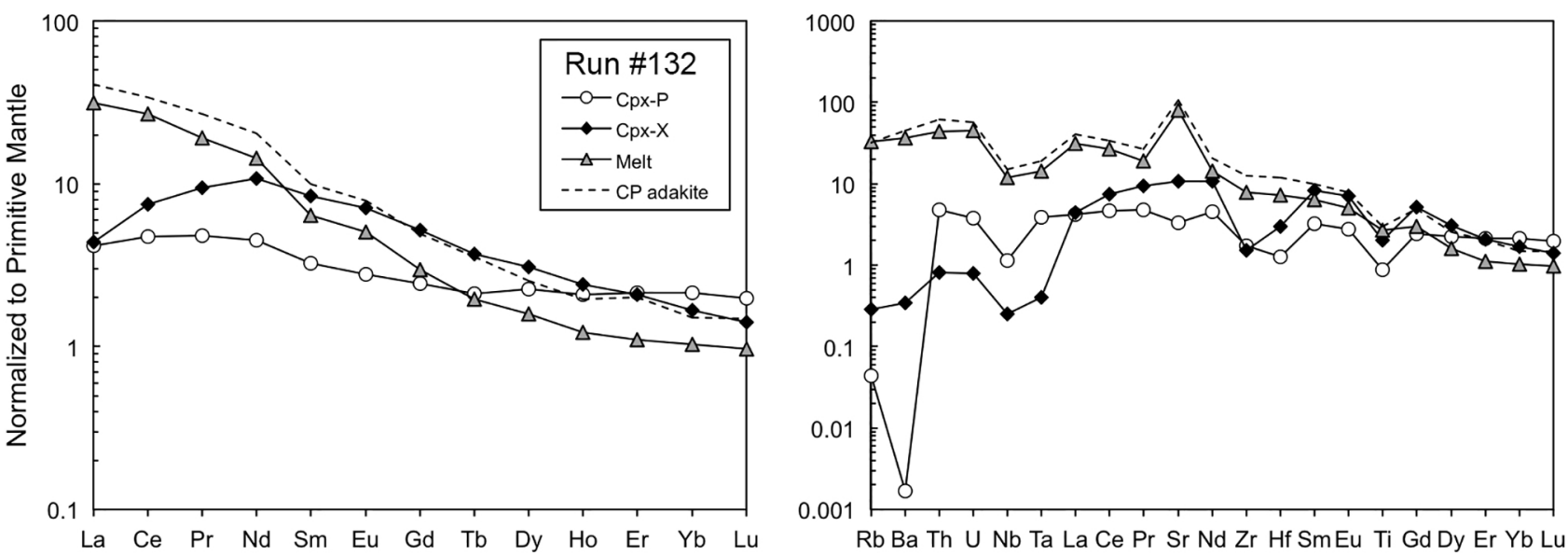

Figure 4 


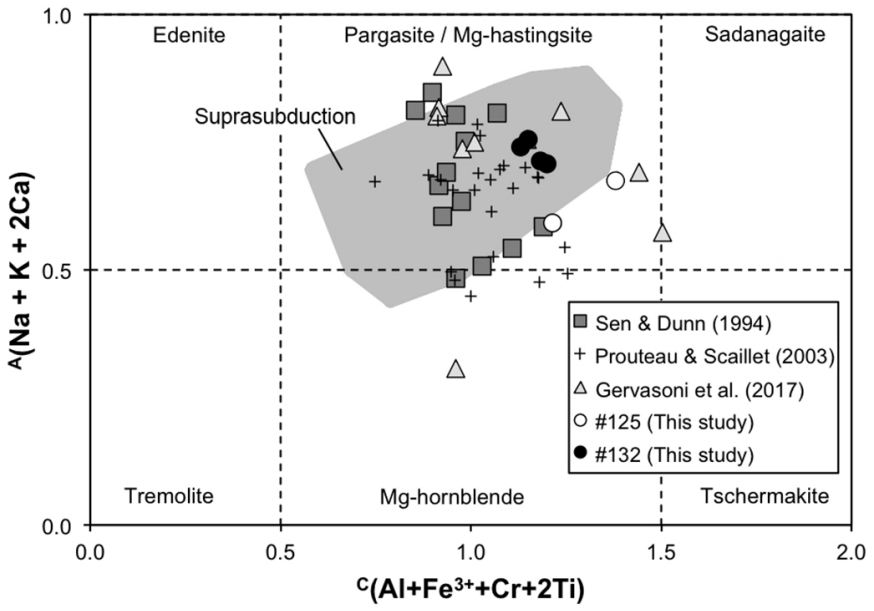

Figure 5 


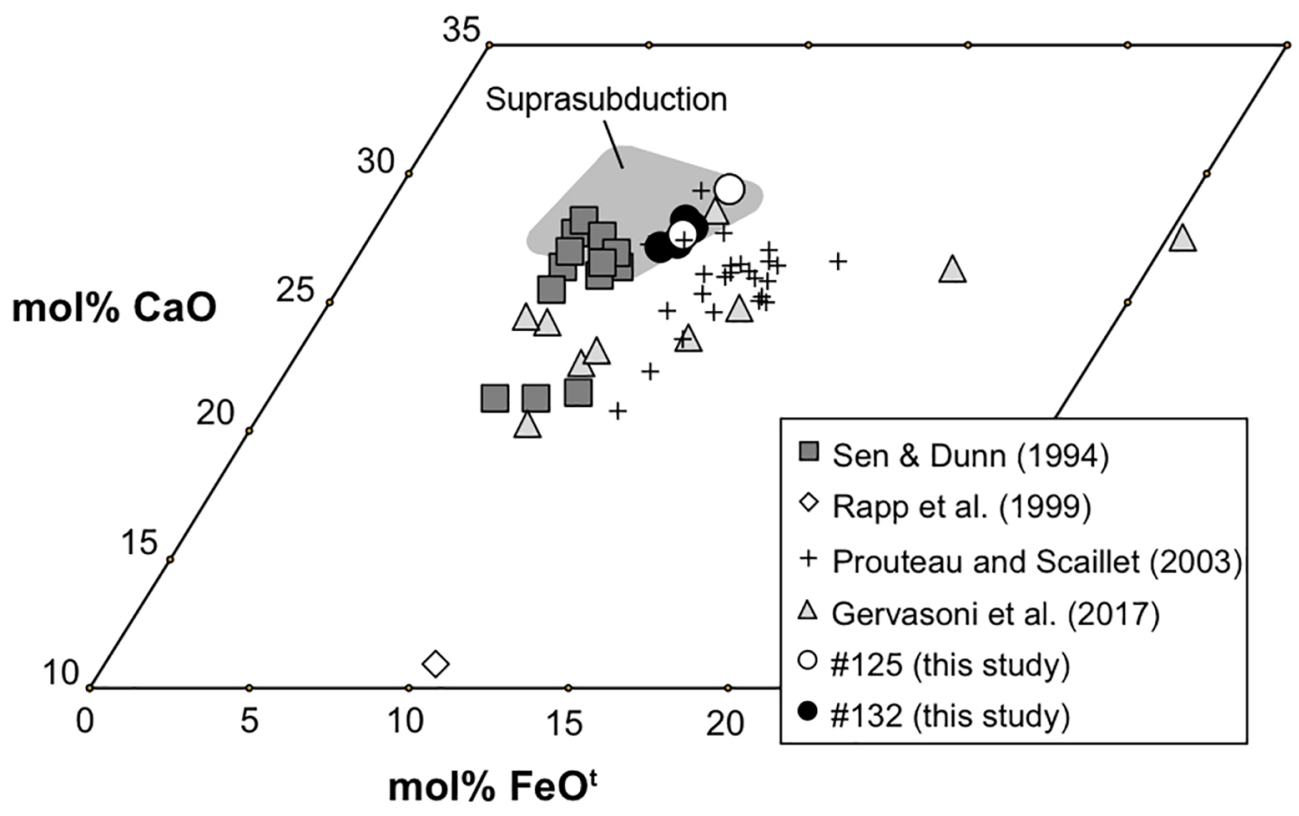

Figure 6 